\title{
Enhanced Component Performance Study: Air-Operated Valves 1998-2014
}

\author{
John A. Schroeder
}

November 2015

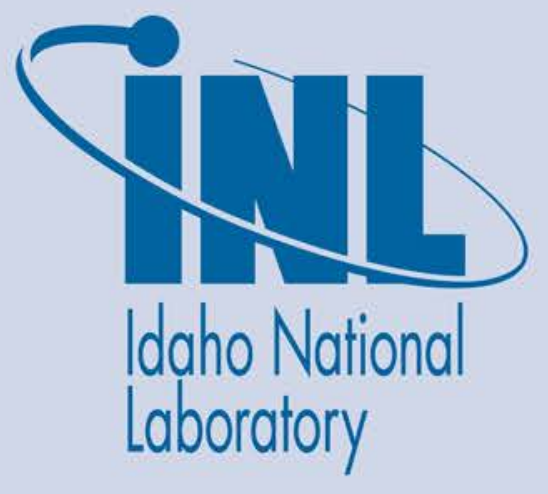

The INL is a U.S. Department of Energy National Laboratory operated by Battelle Energy Alliance 
NOTICE

This information was prepared as an account of work sponsored by an agency of the U.S. Government. Neither the U.S. Government nor any agency thereof, nor any of their employees, makes any warranty, express or implied, or assumes any legal liability or responsibility for any third party's use, or the results of such use, of any information, apparatus, product, or process disclosed herein, or represents that its use by such third party would not infringe privately owned rights. The views expressed herein are not necessarily those of the U.S. Nuclear Regulatory Commission. 


\title{
Enhanced Component Performance Study: Air-Operated Valves 1998-2014
}

\author{
John A. Schroeder
}

Update Completed November 2015

Idaho National Laboratory

Risk Assessment and Management Services Department Idaho Falls, Idaho 83415

http://www.inl.gov

Prepared for the Division of Risk Assessment Office of Nuclear Regulatory Research

U.S. Nuclear Regulatory Commission NRC Agreement Number NRC-HQ-14-D-0018 



\begin{abstract}
This report presents a performance evaluation of air-operated valves (AOVs) at U.S. commercial nuclear power plants. The data used in this study are based on the operating experience failure reports from fiscal year 1998 through 2014 for the component reliability as reported in the Institute of Nuclear Power Operations (INPO) Consolidated Events Database (ICES). The AOV failure modes considered are failure-to-open/close, failure to operate or control, and spurious operation. The component reliability estimates and the reliability data are trended for the most recent 10-year period while yearly estimates for reliability are provided for the entire active period. One statistically significant trend was observed in the AOV data: The frequency of demands per reactor year for valves recording the fail-to-open or fail-to-close failure modes, for highdemand valves (those with greater than twenty demands per year), was found to be decreasing. The decrease was about three percent over the ten year period trended.
\end{abstract}




\section{CONTENTS}

ABSTRACT iii

ACRONYMS ix

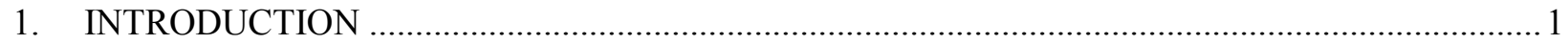

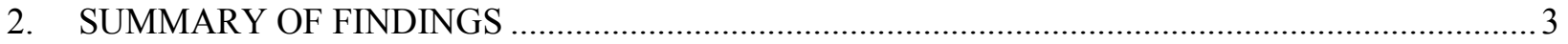

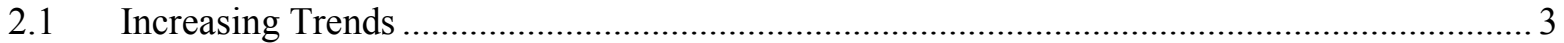

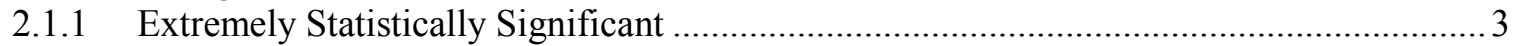

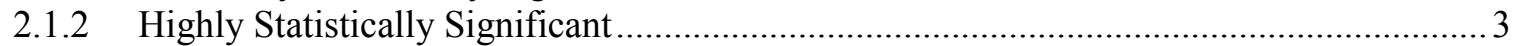

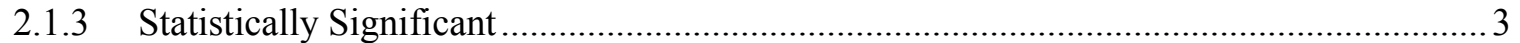

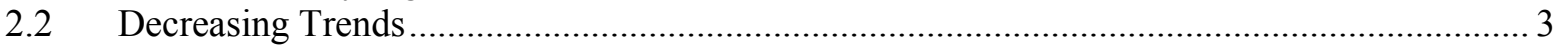

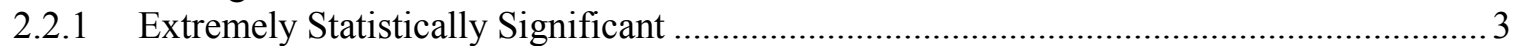

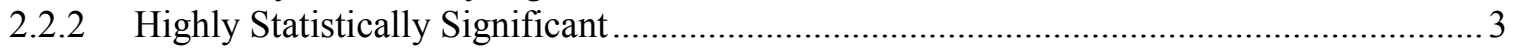

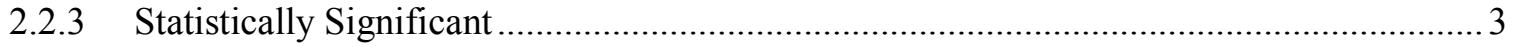

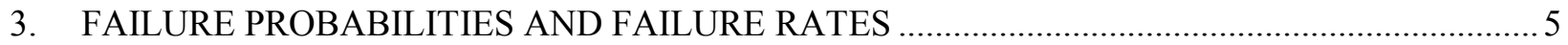

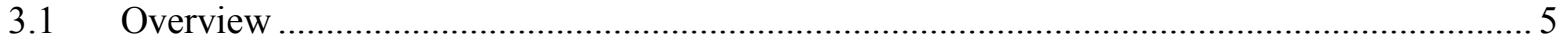

3.2 AOV Failure Probability and Failure Rate Trends ............................................................. 6

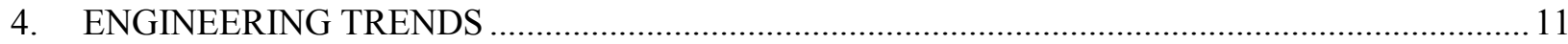

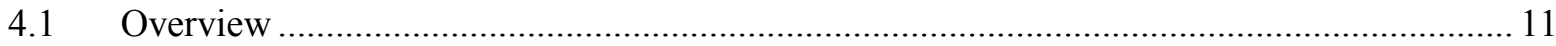

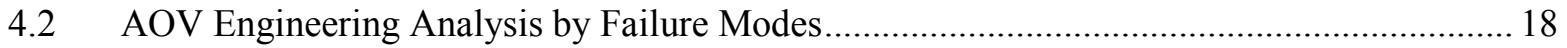

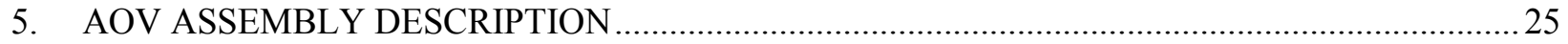

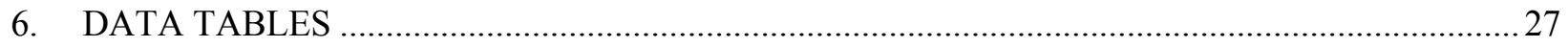

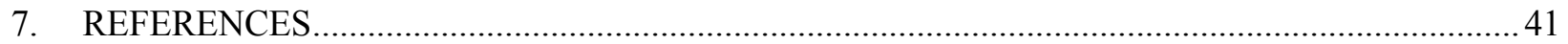

\section{FIGURES}

Figure 1. Failure probability estimate trend for AOV FTOC, all systems, industry-wide trend for low-demand AOVs.

Figure 2. Failure probability estimate trend for AOV FTOC, all systems, industry-wide trend for high-demand AOVs.

Figure 3. Failure rate estimate trend for AOV FTOP, all systems, industry-wide trend for lowdemand AOVs.

Figure 4. Failure rate estimate trend for AOV FTOP, all systems, industry-wide trend for highdemand AOVs. 
Figure 5. Failure rate estimate trend for AOV SO, all systems, industry-wide trend for lowdemand AOVs.

Figure 6. Failure rate estimate trend for AOV SO, all systems, industry-wide trend for highdemand AOVs.

Figure 7. Frequency (demands per reactor year) of low-demand AOV FTOC demands. 11

Figure 8. Frequency (demands per reactor year) of high-demand AOV FTOC demands. 12

Figure 9. Frequency (failures per reactor year) of low-demand AOV FTOC events. 12

Figure 10. Frequency (failures per reactor year) of high-demand AOV FTOC events. 13

Figure 11. Frequency (failures per reactor year) of low-demand AOV FTOP events. 13

Figure 12. Frequency (failures per reactor year) of high-demand AOV FTOP events 14

Figure 13. Frequency (failures per reactor year) of low-demand AOV SO events. 14

Figure 14. Frequency (failures per reactor year) of high-demand AOV SO events. 15

Figure 15. AOV failure event breakdown by subcomponent, failure mode, and demand rate. 20

Figure 16. AOV failure event breakdown by cause group, failure mode, and demand rate 21

Figure 17. AOV failure event breakdown by method of detection, failure mode, and demand rate .22

Figure 18. AOV failure event breakdown by recoverability, failure mode, and demand rate .23

\section{TABLES}

Table 1. Summary of AOV counts in the systems in which they are found. 5

Table 2. 2010 Update industry-wide distributions of $\mathrm{p}$ (failure probability) and $\lambda$ (hourly rate) for AOVs with $\leq 20$ demands/year (from Reference 1).

Table 3. Summary of low-demand AOV failure counts for the FTOC failure mode over time by system..

Table 4. Summary of low-demand AOV failure counts for the FTOP failure mode over time by system..

Table 5. Summary of low-demand AOV failure counts for the SO failure mode over time by system.

Table 6. Summary of high-demand AOV failure counts for the FTOC failure mode over time by system.

Table 7. Summary of high-demand AOV failure counts for the FTOP failure mode over time by system. 
Table 8. Summary of high-demand AOV failure counts for the SO failure mode over time by system.

Table 9. Component failure cause groups.

Table 10. Plot data for Figure 1, failure probability estimate trend for AOV FTOC, all systems, industry-wide trend of low-demand AOVs.

Table 11. Plot data for Figure 2, failure probability estimate trend for AOV FTOC, all systems, industry-wide trend of high-demand AOVs.

Table 12. Plot data for Figure 3, failure rate estimate trend for AOV FTOP, all systems, industrywide trend of low-demand AOVs

Table 13. Plot data for Figure 4, failure rate estimate trend for AOV FTOP, all systems, industrywide trend of high-demand AOVs.

Table 14. Plot data for Figure 5, failure rate estimate trend for AOV SO, all systems, industrywide trend of low-demand AOVs

Table 15. Plot data for Figure 6, failure rate estimate trend for AOV SO, all systems, industrywide trend of high-demand AOVs.

Table 16. Plot data for Figure 7, frequency (demands per reactor year) of low-demand AOV FTOC demands.

Table 17. Plot data for Figure 8, frequency (demands per reactor year) of high-demand AOV FTOC demands.

Table 18. Plot data for Figure 9, frequency (failures per reactor year) of low-demand AOV FTOC events.

Table 19. Plot data for Figure 10, frequency (failures per reactor year) of high-demand AOV FTOC events.

Table 20. Plot data for Figure 11, frequency (failures per reactor year) of low-demand AOV FTOP events.

Table 21. Plot data for Figure 12, frequency (failures per reactor year) of high-demand AOV FTOP events.

Table 22. Plot data for Figure 13, frequency (failures per reactor year) of low-demand AOV SO events.

Table 23. Plot data for Figure 14, frequency (failures per reactor year) of high-demand AOV SO events. 
Enhanced Component Performance Study Air-Operated Valves
2014 Update November 2015 


\section{ACRONYMS}

\begin{tabular}{|c|c|}
\hline $\begin{array}{l}\text { AFW } \\
\text { AOV }\end{array}$ & $\begin{array}{l}\text { auxiliary feed water } \\
\text { air-operated valve }\end{array}$ \\
\hline $\mathrm{CCW}$ & component cooling water \\
\hline CRD & control rod drive \\
\hline CSR & containment spray recirculation \\
\hline EPIX & Equipment Performance and Information Exchange \\
\hline FTOC & failure-to-open/close \\
\hline FTOP & failure to operate or control \\
\hline FY & fiscal year \\
\hline $\mathrm{HCI}$ & high pressure cooling injection \\
\hline HPI & high pressure injection \\
\hline ICES & INPO Consolidated Events Database \\
\hline INPO & Institute of Nuclear Power Operations \\
\hline ISO & isolation condenser \\
\hline LCS & low pressure core spray \\
\hline MSPI & Mitigating Systems Performance Index \\
\hline NPRDS & Nuclear Plant Reliability Data System \\
\hline RCI & reactor core isolation cooling \\
\hline RCS & reactor coolant system \\
\hline RHR & residual heat removal \\
\hline SO & spurious operation \\
\hline SWN & service water - normally running \\
\hline SWS & service water - normally in standby \\
\hline
\end{tabular}




\section{Enhanced Component Performance Study: Air-Operated Valves 1998-2014}

\section{INTRODUCTION}

This report presents a performance evaluation of air-operated valves (AOVs) at U.S. commercial nuclear power plants. The objective of the updated component performance studies is to obtain annual performance trends of failure rates and probabilities and to present an analysis of factors that could influence the component trends.

The data used in this study are based on the operating experience failure reports from the Institute of Nuclear Power Operations' (INPO') Consolidated Events Database (ICES) from fiscal year (FY) 1998 through FY 2014. Data for valves demanded more than 20 times per year (high-demand) are reported separately from the data for lesser-used (low-demand) valves. The AOV failure modes considered are failure-to-open/close (FTOC), failure to operate or control (FTOP), and spurious operation (SO). Annual failure probabilities (failures per demand) are provided for FTOC events and annual failure rates (failures per valve hour) are provided for FTOP and SO events.

Like the NRC's Industry Trend Program [1], each of the estimates is trended for the most recent 10year period. Yearly estimates are provided for the entire active period.

This study is an update of NUREG/CR-1715, Vol. 3 [2], which was published in 2001. That study relied on operating experience obtained from licensee event reports, the Nuclear Plant Reliability Data System (NPRDS), and ICES. The ICES database, which includes the Mitigating Systems Performance Index (MSPI) as a subset, has matured to the point where component availability and reliability can be estimated with a higher degree of accuracy. In addition, the population of data in ICES has been growing and is much larger than the population used in the previous study.

This report provides an overview of operational data and makes no attempt to estimate values for use in probabilistic risk assessments. The 2010 Component Reliability Update [3], which is an update to Industry-Average Performance for Components and Initiating Events at U.S Commercial Nuclear Power Plants [4], reports the current AOV unreliability estimates for probabilistic risk assessments. Estimates from that report are included herein, for comparisons.

Engineering analyses were also performed, first with respect to time period. In Section 4.1, the same failures used in Section 3 are used to compute estimates of overall failure frequencies per plant reactor year. Frequencies of demands per plant reactor year for both groupings of AOVs are also provided for each FY. As in Section 3, each of the estimates is trended for the most recent 10-year period. The frequencies show general industry performance and are not based on the number of valves at each plant.

Section 4.2 provides breakdowns of the failures for each failure mode for each valve grouping. The analyses are based on the following factors: sub-component, failure cause, detection method, and recovery.

An overview of the trending methods, glossary of terms, and abbreviations can be found in the Overview and Reference document [5] on the Reactor Operational Experience Results and Databases web page. 


\section{SUMMARY OF FINDINGS}

The results of this study are summarized in this section. Of particular interest is the existence of any statistically significant ${ }^{\mathrm{a}}$ increasing trends. In this update, three statistically significant trends were identified in the AOV data. Note that the same failure counts (numerators) are used in Figures 3 and 11.

\subsection{Increasing Trends}

\subsubsection{Extremely Statistically Significant}

- None.

\subsubsection{Highly Statistically Significant}

- None

\subsubsection{Statistically Significant}

- The failure rate estimate (failures per valve hour) for fail-to-operate, across all systems, for lowdemand valves (those with less than or equal to twenty demands per reactor year), was found to be increasing (Figure 3). This trend was independently evaluated using Poisson regression instead of the iteratively re-weighted least squares routine currently built into the annual update software and was found NOT to be statistically significant.

\subsection{Decreasing Trends}

\subsubsection{Extremely Statistically Significant}

- None

\subsubsection{Highly Statistically Significant}

- None

\subsubsection{Statistically Significant}

- The frequency of demands per reactor year for valves recording the fail-to-open or fail-to-close failure modes, for high-demand valves (those with greater than twenty demands per year), was found to be decreasing (Figure 8). This trend was independently evaluated using Poisson regression instead of the iteratively re-weighted least squares routine currently built into the annual update software and was found to be HIGHLY statistically significant. The decrease was about three percent over the ten year period trended.

- The frequency of failure per reactor year for fail-to-operate, across all systems, for low-demand valves, was found to be increasing (Figure 11). This trend was independently evaluated using Poisson regression instead of the iteratively re-weighted least squares routine currently built into the annual update software and was found NOT to be statistically significant.

a. Statistical significance is defined in terms of the 'p-value.' A p-value is a probability indicating whether to accept or reject the null hypothesis that there is no trend in the data. P-values of less than or equal to 0.05 indicate that we are $95 \%$ confident that there is a trend in the data (reject the null hypothesis of no trend.) By convention, we use the "Michelin Guide" scale: p-value $<0.05$ (statistically significant), p-value $<0.01$ (highly statistically significant); -value $<0.001$ (extremely statistically significant). 
Enhanced Component Performance Study 


\section{FAILURE PROBABILITIES AND FAILURE RATES}

\subsection{Overview}

Trends of industry-wide failure probabilities and failure rates for AOVs have been calculated from the operating experience for the FTOC, FTOP, and SO failure modes. The AOV data set obtained from ICES was partitioned to low-demand AOVs (those with less than or equal to 20 demands/year) and highdemand AOVs (those with greater than 20 demands/year) and includes AOVs in the systems listed in Table 1.

Table 2 shows industry-wide failure probability and failure rate results for low-demand AOVs from Reference [3], hence forth referred to as the 2010 Update results. No 2010 Update results are shown for high-demand AOVs because Reference [3] does not provide them. The 2010 Update results are provided for comparison purposes and are important because they are intended for use in probabilistic risk assessment (PRA). The results in this section demonstrate the extent to which the 2010 Update results remain suitable estimates for use in PRA.

The AOVs are assumed to operate both when the reactor is critical and during shutdown periods. The number of valves in operation is assumed to be constant throughout the study period. All demand types are considered - testing, non-testing, and, as applicable, engineered safety feature demands.

Table 1. Summary of AOV counts in the systems in which they are found.

\begin{tabular}{|c|c|c|c|c|}
\hline \multirow[b]{2}{*}{ System } & \multirow[b]{2}{*}{ Description } & \multicolumn{3}{|c|}{ AOV Count } \\
\hline & & Total & Low Demand & High Demand \\
\hline AFW & Auxiliary feedwater & 360 & 195 & 165 \\
\hline $\mathrm{CCW}$ & Component cooling water & 440 & 299 & 141 \\
\hline CRD & Control rod drive & 117 & 66 & 51 \\
\hline CSR & Containment spray recirculation & 30 & 28 & 2 \\
\hline $\mathrm{HCl}$ & High pressure coolant injection & 14 & 7 & 7 \\
\hline $\mathrm{HPI}$ & High pressure injection & 94 & 70 & 24 \\
\hline ISO & Isolation condenser & 10 & 6 & 4 \\
\hline LCS & Low pressure core spray & 12 & 10 & 2 \\
\hline $\mathrm{RCl}$ & Reactor core isolation & 8 & 6 & 2 \\
\hline RCS & Reactor coolant & 113 & 52 & 61 \\
\hline RHR & Residual heat removal & 272 & 138 & 134 \\
\hline SWN & Normally running service water & 511 & 296 & 215 \\
\hline \multirow[t]{2}{*}{ SWS } & Standby service water & 55 & 20 & 35 \\
\hline & Total & 2036 & 1193 & 843 \\
\hline
\end{tabular}

Table 2. 2010 Update industry-wide distributions of $p$ (failure probability) and $\lambda$ (hourly rate) for AOVs with $\leq 20$ demands/year (from Reference 1).

\begin{tabular}{cccccccc}
\hline \multirow{2}{*}{$\begin{array}{c}\text { Failure } \\
\text { Mode }\end{array}$} & $\mathbf{5 \%}$ & Median & Mean & $\mathbf{9 5 \%}$ & Type & $\boldsymbol{\alpha}$ & $\boldsymbol{\beta}$ \\
\hline FTOC & $6.27 \mathrm{E}-05$ & $6.86 \mathrm{E}-04$ & $9.51 \mathrm{E}-04$ & $2.74 \mathrm{E}-03$ & Beta & 1.11 & $1.168 \mathrm{E}+03$ \\
FTOP & $2.66 \mathrm{E}-08$ & $1.93 \mathrm{E}-07$ & $2.49 \mathrm{E}-07$ & $6.59 \mathrm{E}-07$ & Gamma & 1.42 & $5.719 \mathrm{E}+06$ \\
SO & $2.04 \mathrm{E}-09$ & $7.46 \mathrm{E}-08$ & $1.31 \mathrm{E}-07$ & $4.49 \mathrm{E}-07$ & Gamma & 0.68 & $5.211 \mathrm{E}+06$ \\
\hline
\end{tabular}




\subsection{AOV Failure Probability and Failure Rate Trends}

Trends in failure probabilities and failure rates are shown in Figures 1-6. The data for the trend plots are contained in Tables $10-15$, respectively.

In the plots, the means of the posterior distributions from the Bayesian update process were trended across the years. The posterior distributions were also used for the vertical bounds for each year. The 5th and 95th percentiles of these distributions give an indication of the relative variation from year to year in the data. When there are no failures, the interval is larger than the interval for years when there are one or more failures. The larger interval reflects the uncertainty that comes from having little information in that year's data. Such uncertainty intervals are determined by the prior distribution. In each plot, in each year, a relatively "flat" constrained noninformative prior distribution is used, which has large bounds. The mean of such a prior distribution is the number of failures plus 0.5 divided by the number of demands plus 1.0 (for probabilities) or valve hours (for rates).

The horizontal curves plotted around the regression lines in the graphs form 90 percent simultaneous confidence bands for the fitted lines. The bounds are larger than ordinary confidence intervals for the trended values because they form a band that has a $90 \%$ probability of containing the entire line. In the lower left hand corner of the trend figures, the regression p-values are reported. They come from a statistical test on whether the slope of the regression line might be zero. Low p-values indicate that the slopes are not likely to be zero and that trends exist. Further information on the trending methods is provided in Section 2 of the Overview and Reference document [5]. The industry values from the 2010 Update are also shown for comparison. 


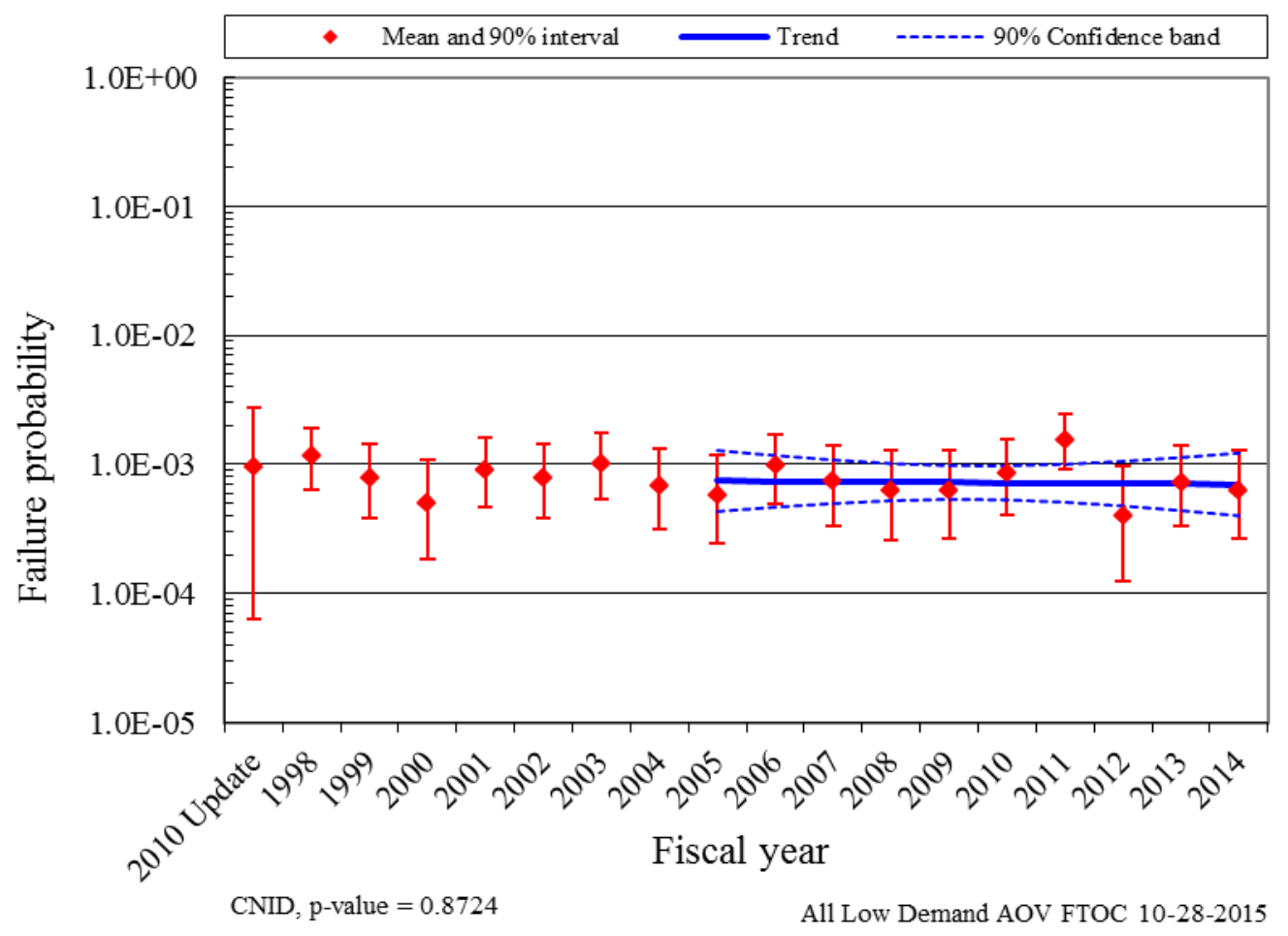

Figure 1. Failure probability estimate trend for AOV FTOC, all systems, industry-wide trend for lowdemand AOVs.

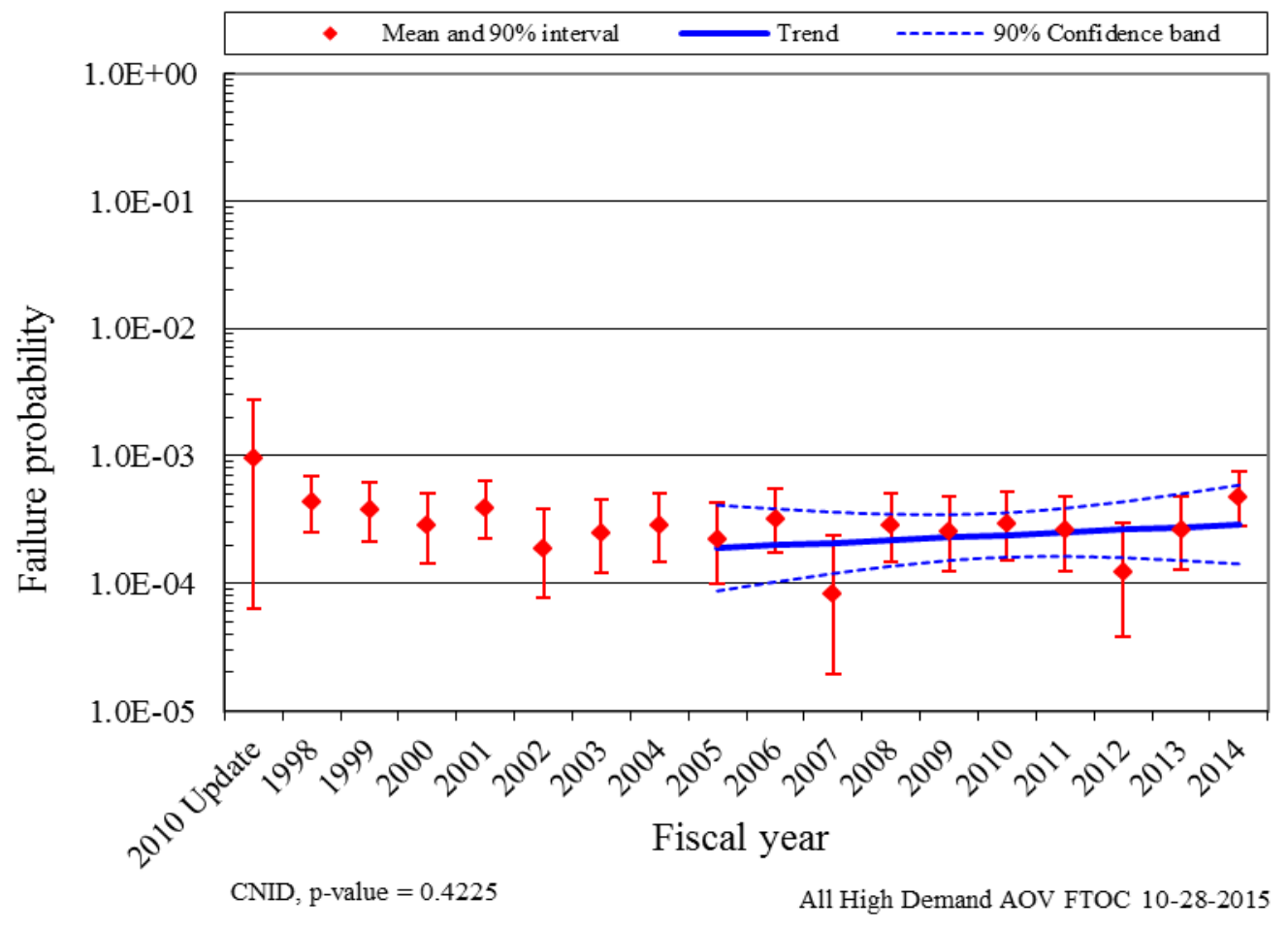

Figure 2. Failure probability estimate trend for AOV FTOC, all systems, industry-wide trend for highdemand AOVs. 


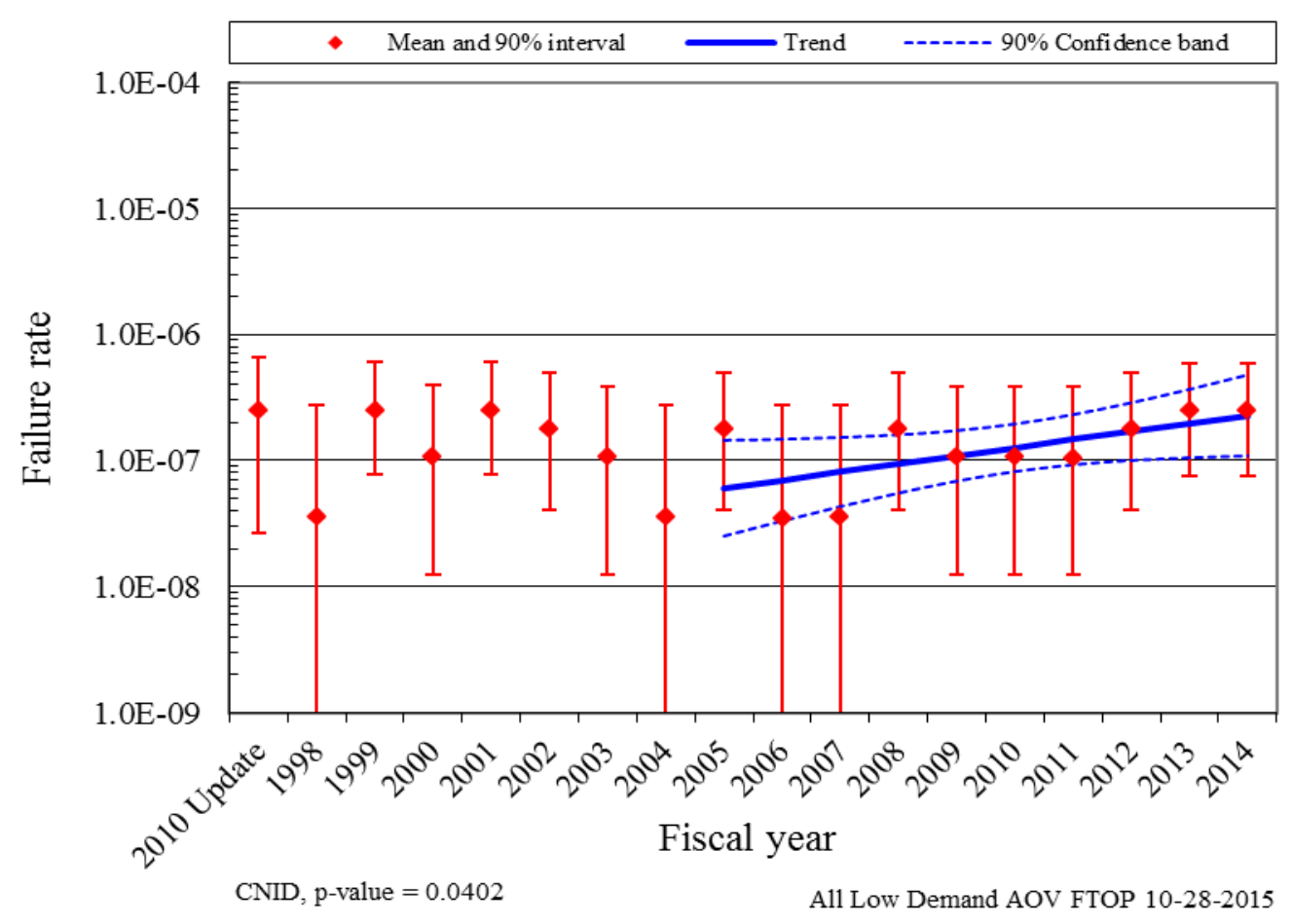

Figure 3. Failure rate estimate trend for AOV FTOP, all systems, industry-wide trend for low-demand AOVS.

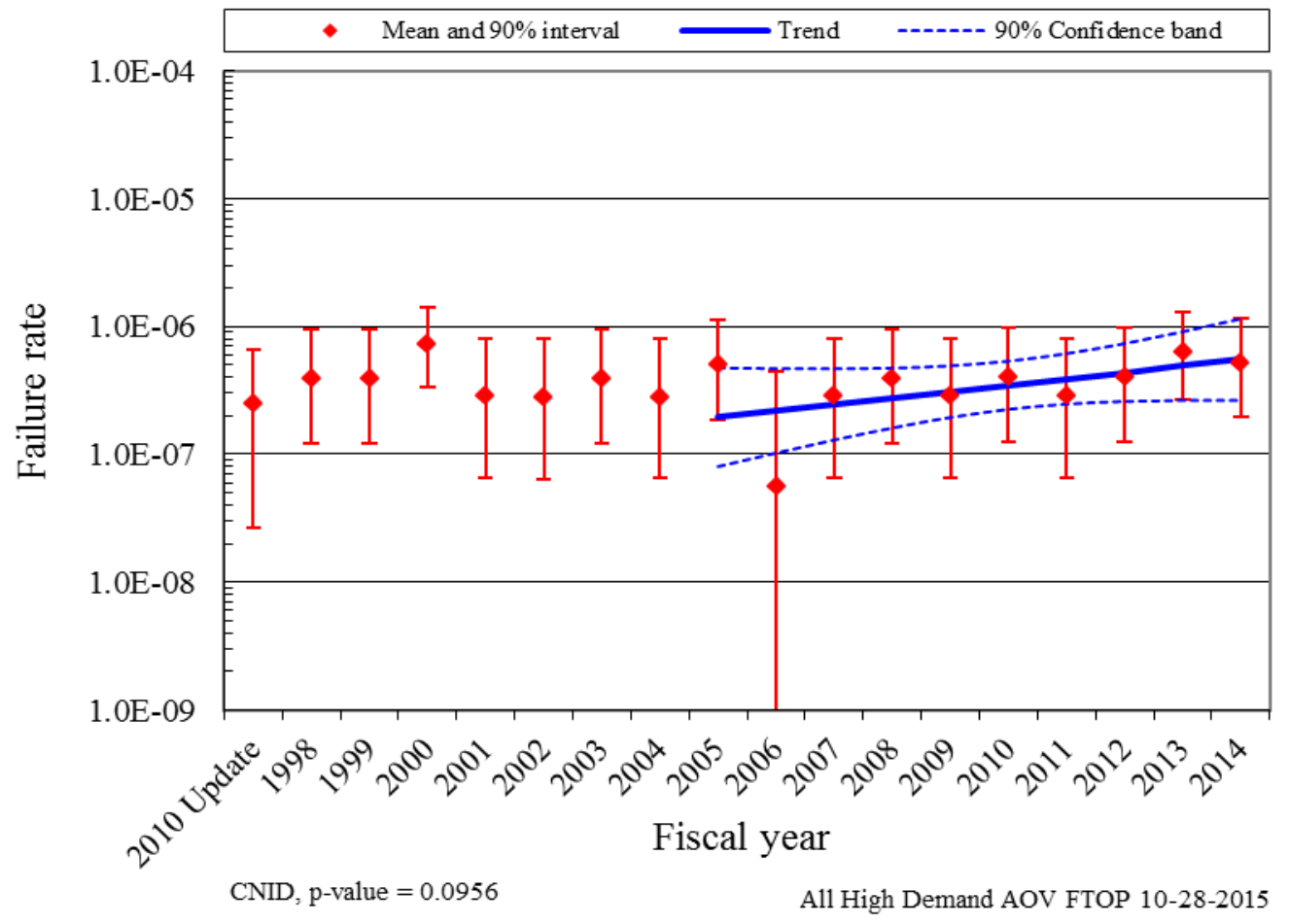

Figure 4. Failure rate estimate trend for AOV FTOP, all systems, industry-wide trend for high-demand AOVS. 


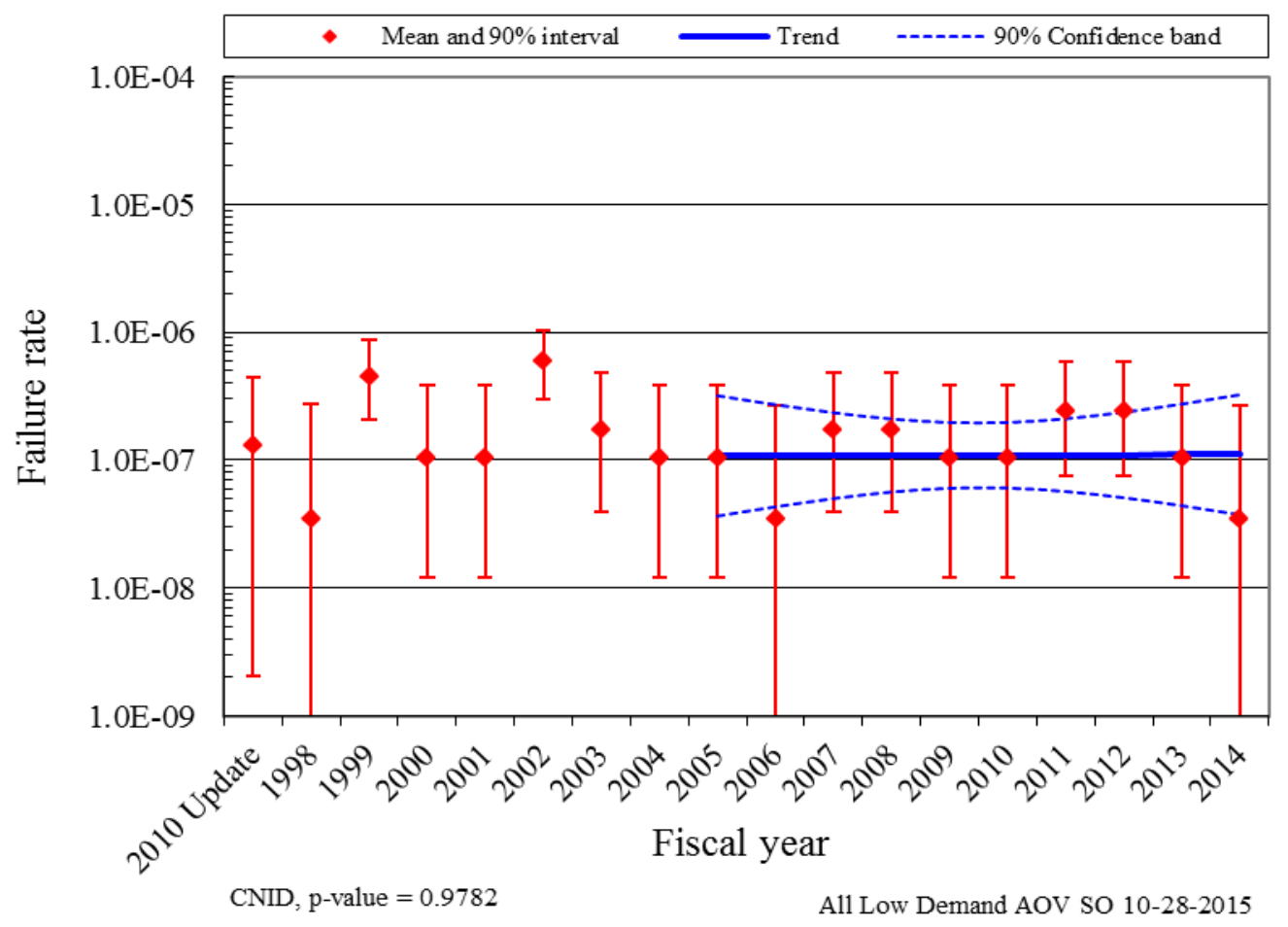

Figure 5. Failure rate estimate trend for AOV SO, all systems, industry-wide trend for low-demand AOVS.

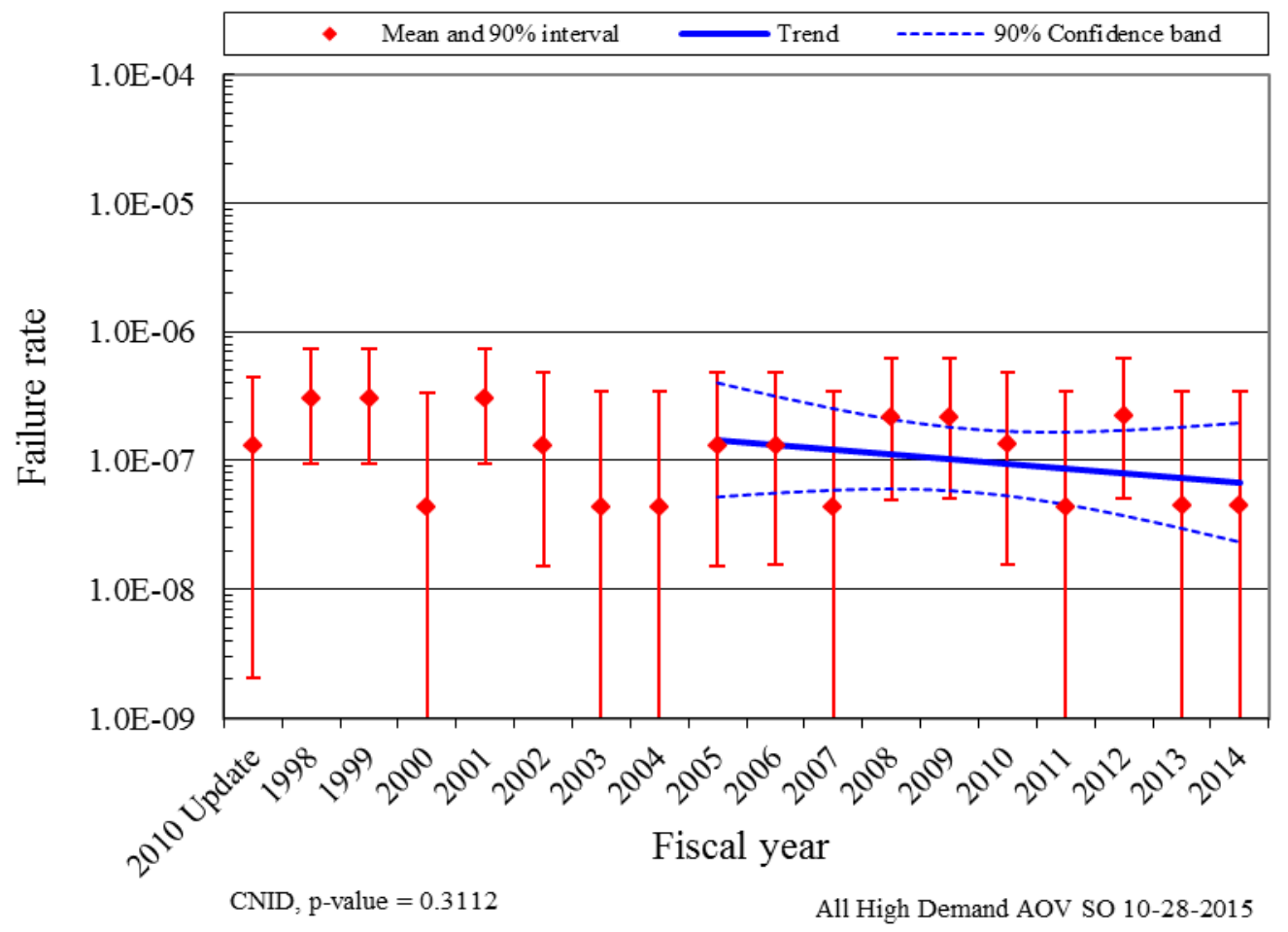

Figure 6. Failure rate estimate trend for AOV SO, all systems, industry-wide trend for high-demand AOVS. 
Enhanced Component Performance Study 


\section{ENGINEERING TRENDS}

\subsection{Overview}

This section presents frequency trends for AOV failures and demands. The data are normalized by reactor year for plants that report data for the equipment being trended. Figure 7 shows the trend for total industry AOV demands among low-demand AOVs. Figure 9 shows the trend in failure events for the FTOC mode for high-demand AOVs, and Figure 13 shows the trend for SO failure events for these AOVs.

Figure 8 shows the trend for total AOV demands per reactor-year among high-demand AOVs. Figure 10 shows the trend in failure events for the FTOC mode for high-demand AOVs, and Figure 14 shows the trend for SO failure events for these AOVs.

Table 3 summarizes the failures by system, year, and the FTOC failure mode for low-demand AOV demands. Table 4 summarizes the failures by system, year, and the FTOP failure mode for high-demand AOV demands. Table 5 summarizes the failures by system, year, and the SO failure mode for lowdemand AOV demands. .

Table 6 summarizes the failures by system, year, and the FTOC failure mode for high-demand AOV demands. Table 7 summarizes the failures by system, year, and the FTOP failure mode for high-demand AOV demands. Table 8 summarizes the failures by system, year, and the SO failure mode for highdemand AOV demands.

Tables 16-23 provide the plot data for frequency (per reactor year) of AOV demands, FTOC events, FTOP events, and SO events, respectively. The systems from Table 2 are trended together for each figure. The rate methods described in Section 2 of the Overview and Reference document [5] are used.

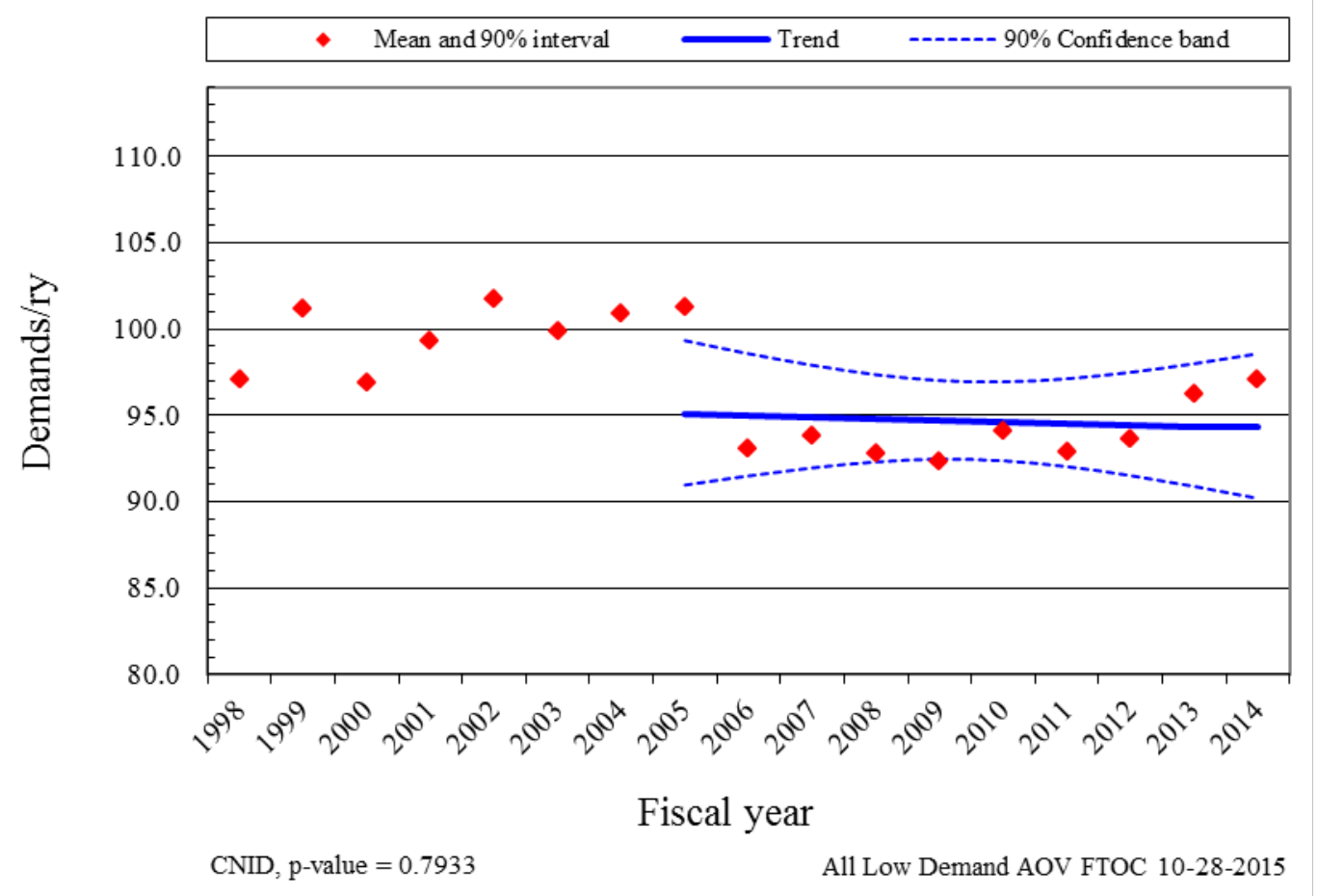

Figure 7. Frequency (demands per reactor year) of low-demand AOV FTOC demands. 


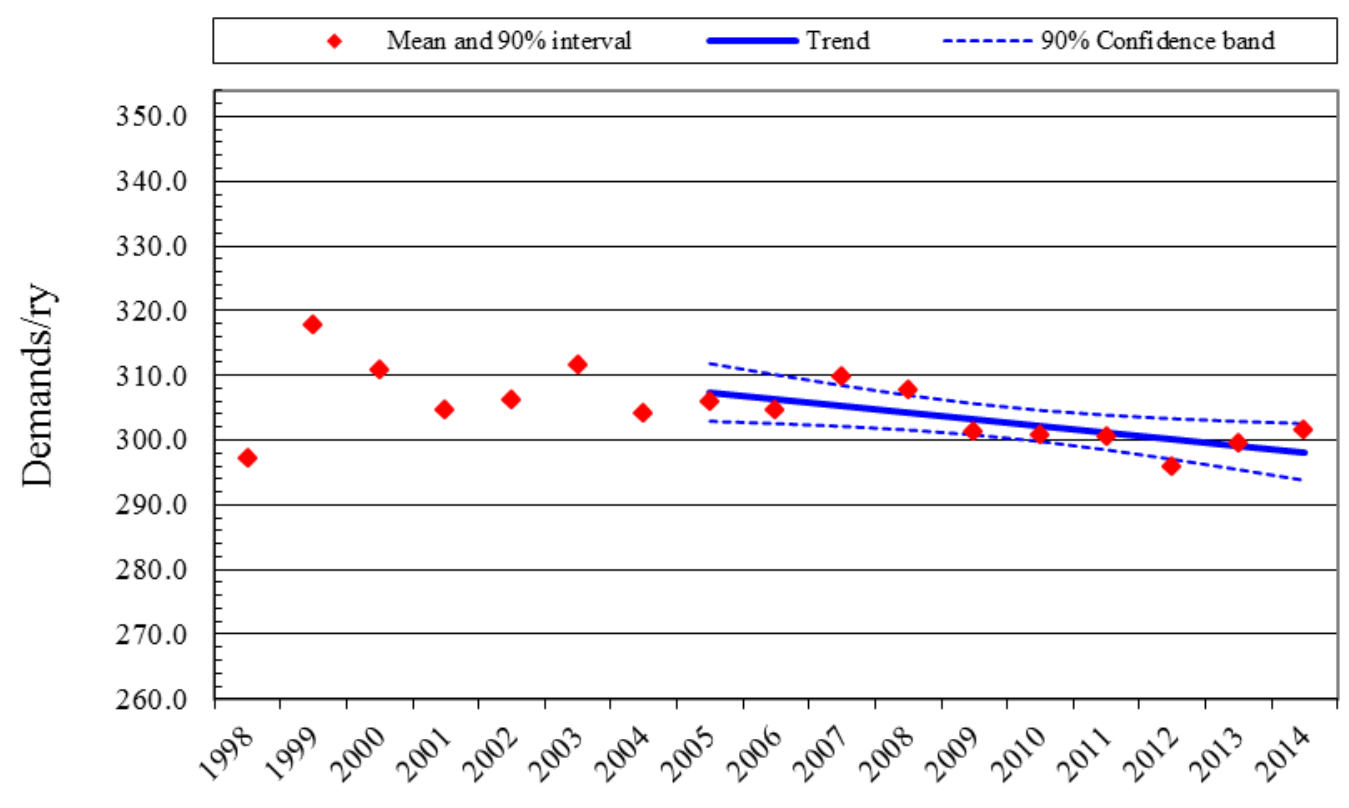

Fiscal year

CNID, p-value $=0.0151$

All High Demand AOV FTOC 10-28-2015

Figure 8. Frequency (demands per reactor year) of high-demand AOV FTOC demands.

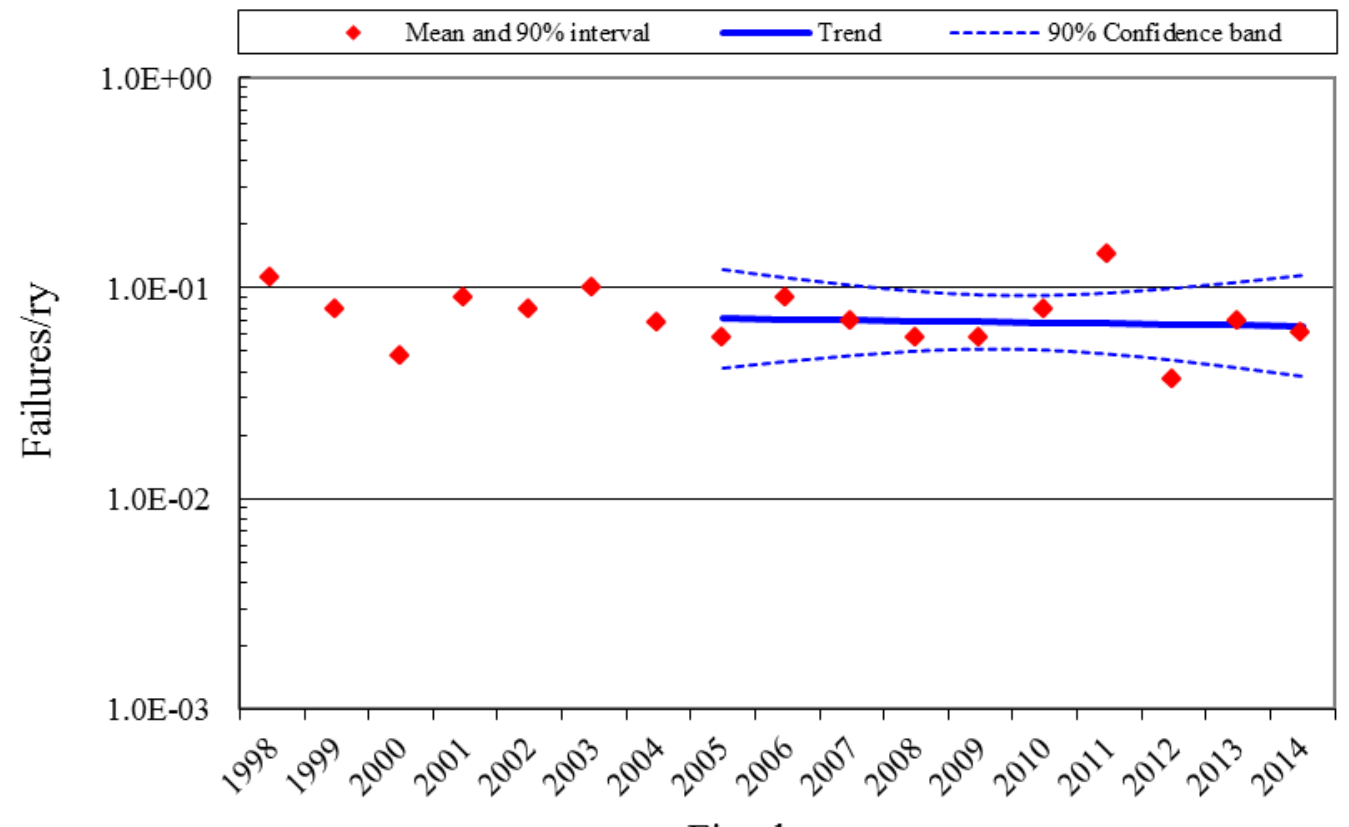

Fiscal year

CNID, p-value $=0.8414$

All Low Demand AOV FTOC 10-28-2015

Figure 9. Frequency (failures per reactor year) of low-demand AOV FTOC events. 


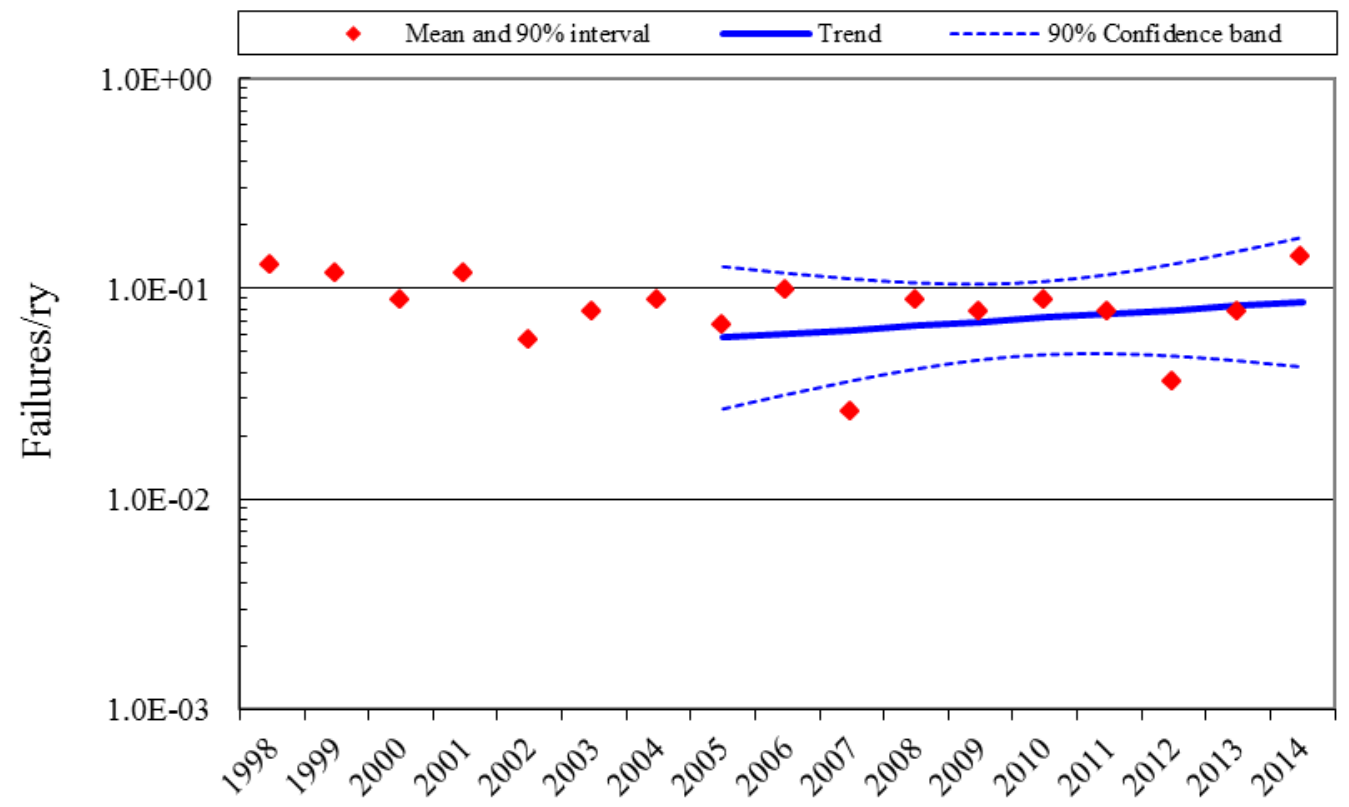

Fiscal year

CNID, $\mathrm{p}$-value $=0.4601$

All High Demand AOV FTOC 10-28-2015

Figure 10. Frequency (failures per reactor year) of high-demand AOV FTOC events.

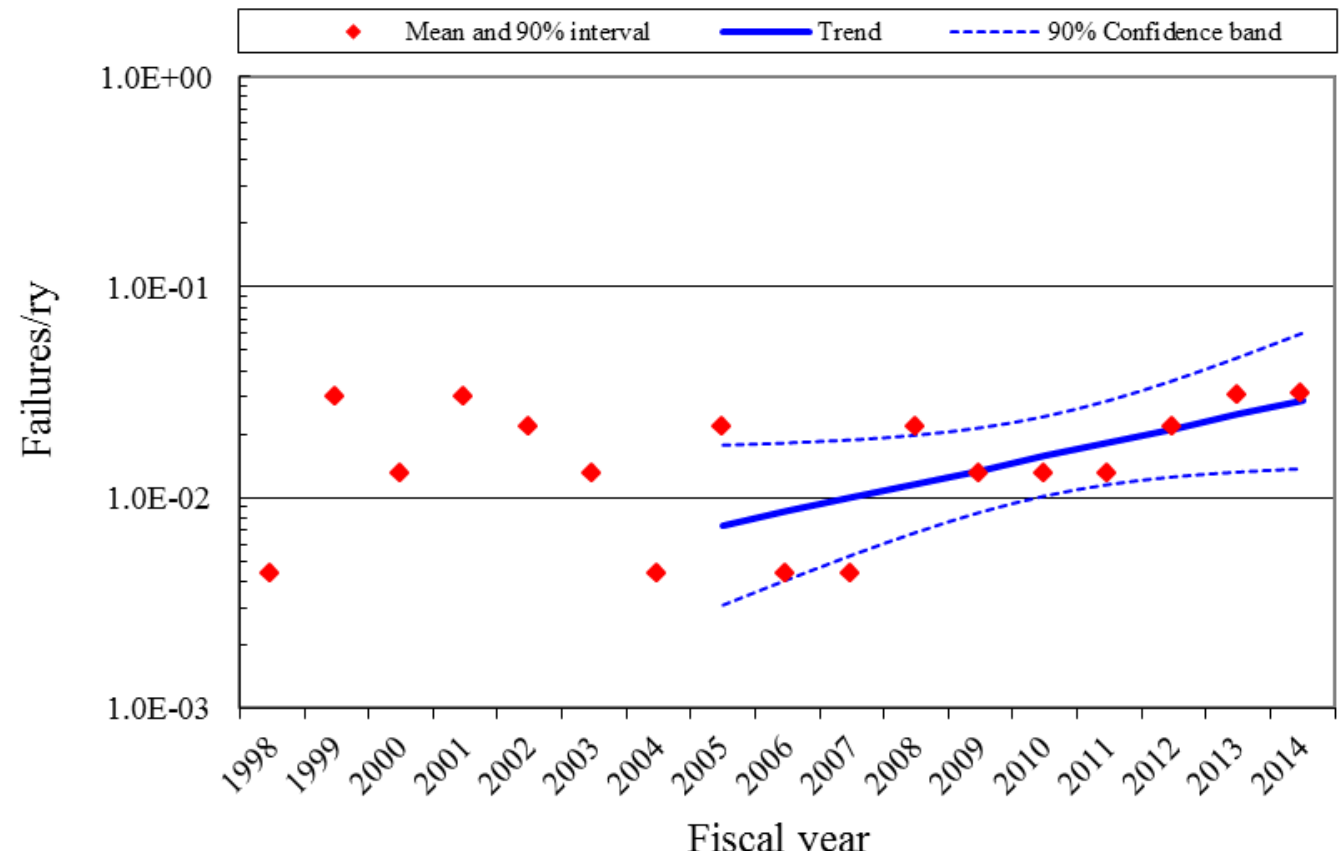

CNID, p-value $=0.0375$

All Low Demand AOV FTOP 10-28-2015

Figure 11. Frequency (failures per reactor year) of low-demand AOV FTOP events. 


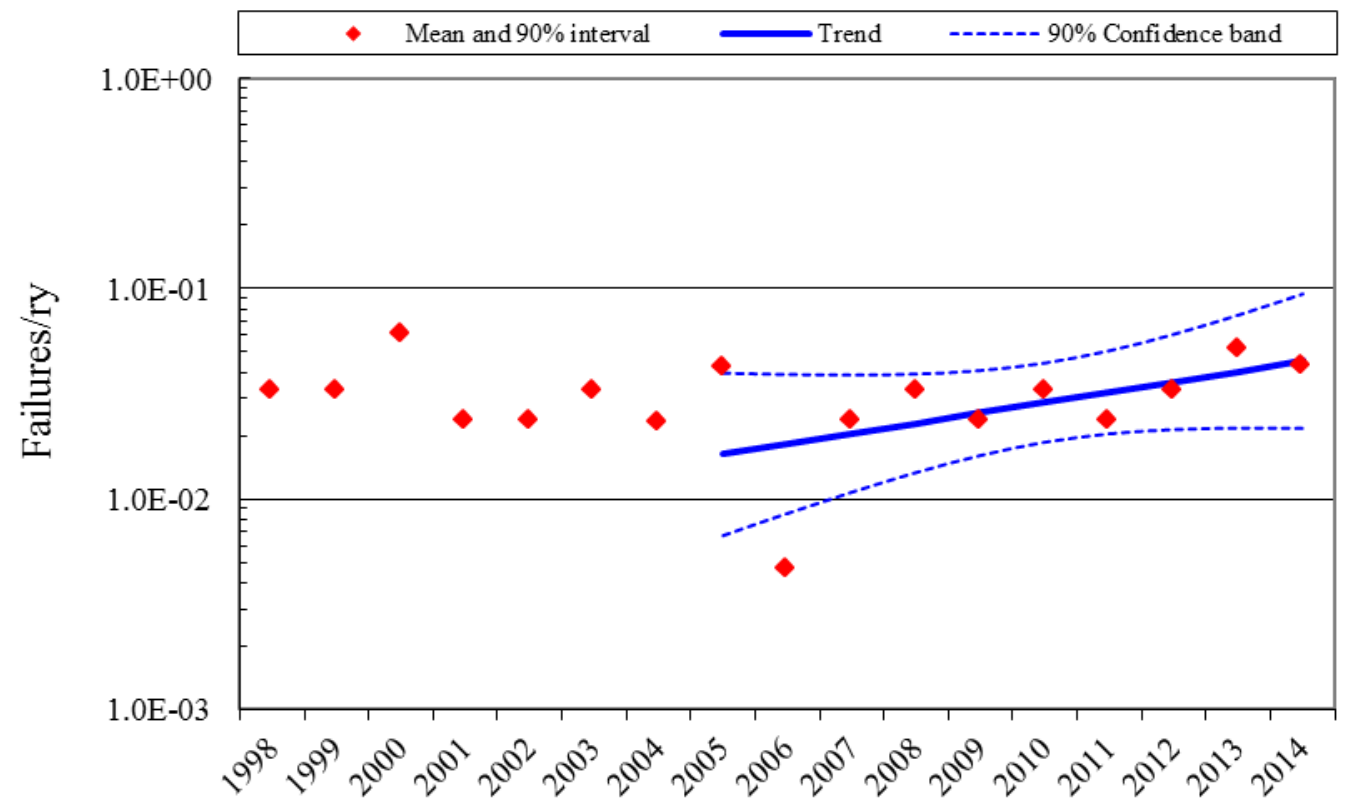

Fiscal year

CNID, p-value $=0.1009$

All High Demand AOV FTOP 10-28-2015

Figure 12. Frequency (failures per reactor year) of high-demand AOV FTOP events.

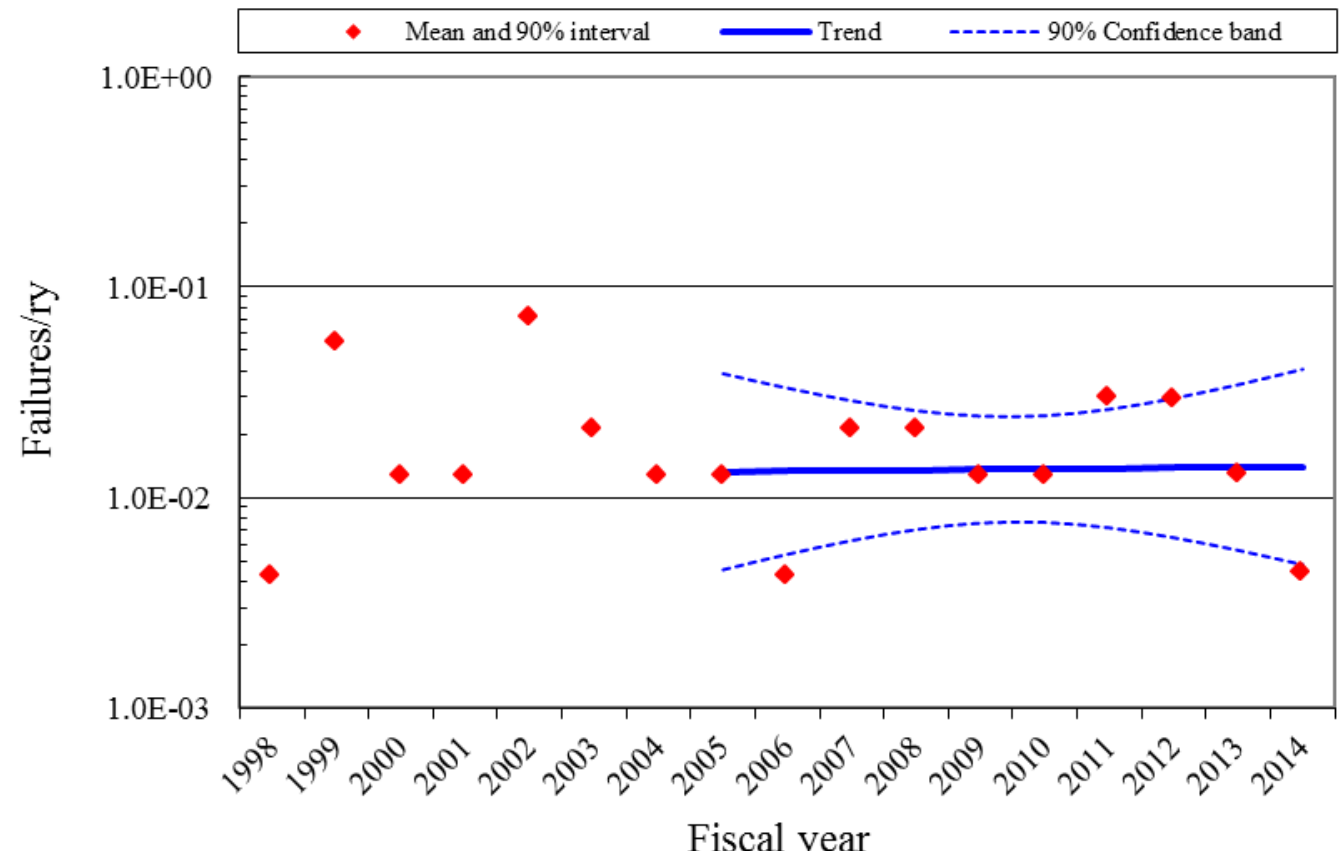

CNID, p-value $=0.9440$

All Low Demand AOV SO 10-28-2015

Figure 13. Frequency (failures per reactor year) of low-demand AOV SO events. 


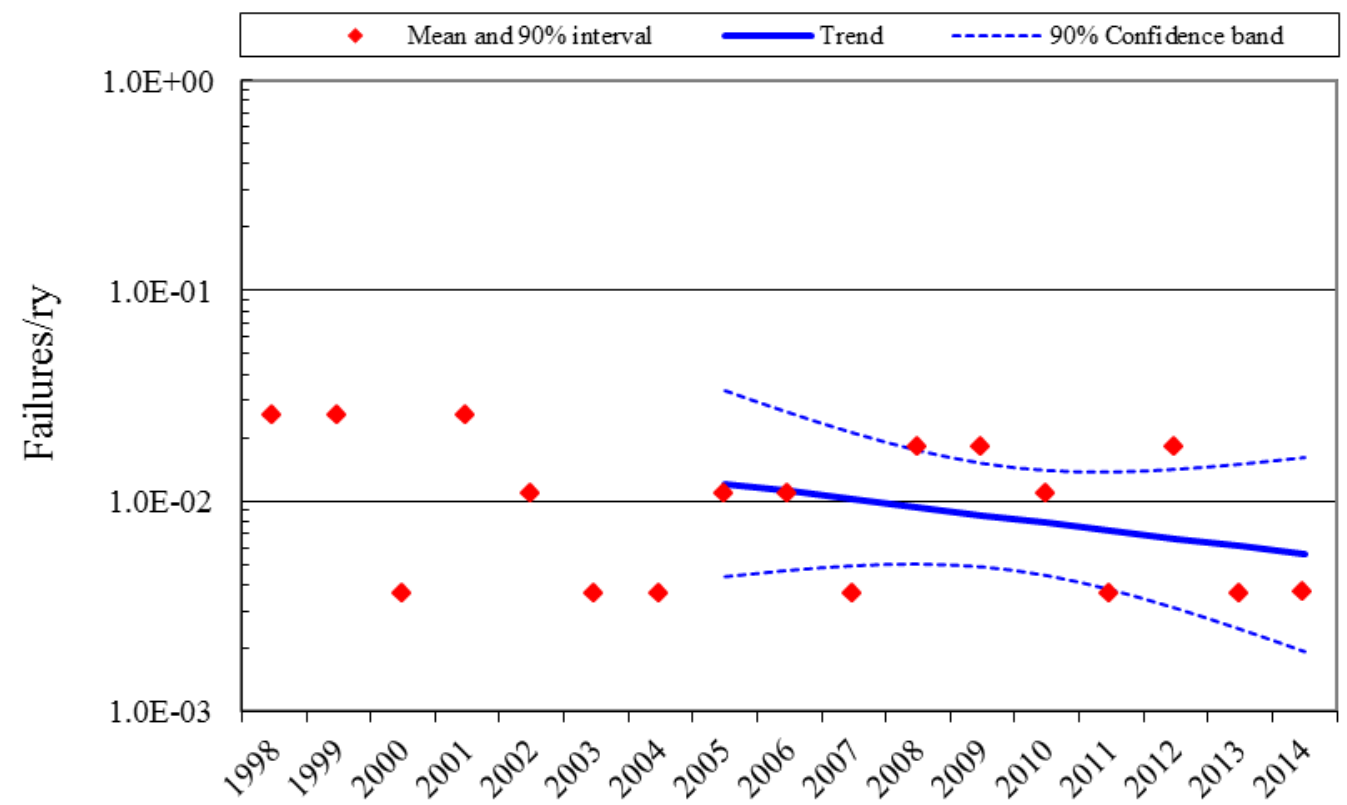

Fiscal year

CNID, $\mathrm{p}$-value $=0.3012$

All High Demand AOV SO 10-28-2015

Figure 14. Frequency (failures per reactor year) of high-demand AOV SO events. 
Table 3. Summary of low-demand AOV failure counts for the FTOC failure mode over time by system.

\begin{tabular}{|c|c|c|c|c|c|c|c|c|c|c|c|c|c|c|}
\hline $\begin{array}{c}\text { System } \\
\text { Code }\end{array}$ & $\begin{array}{l}\text { Valve } \\
\text { Count }\end{array}$ & $\begin{array}{l}\text { Valve } \\
\text { Percent }\end{array}$ & 2005 & 2006 & 2007 & 2008 & 2009 & 2010 & 2011 & 2012 & 2013 & 2014 & Total & $\begin{array}{c}\text { Percent } \\
\text { of } \\
\text { Failures }\end{array}$ \\
\hline AFW & 195 & $16.5 \%$ & 2 & 2 & 1 & & 1 & 3 & & & 1 & & 10 & $15.9 \%$ \\
\hline CCW & 299 & $25.3 \%$ & 1 & 2 & 2 & 1 & & 1 & 3 & & 4 & 4 & 18 & $28.6 \%$ \\
\hline CRD & 66 & $5.6 \%$ & & & & & & & & 1 & & & 1 & $1.6 \%$ \\
\hline CSR & 28 & $2.4 \%$ & 1 & & 1 & & & & & & & & 2 & $3.2 \%$ \\
\hline HPI & 70 & $5.9 \%$ & & 1 & & 1 & & & 3 & & & 1 & 6 & $9.5 \%$ \\
\hline LCS & 10 & $0.8 \%$ & & & & & & & & & & & 0 & $0.0 \%$ \\
\hline $\mathrm{RCl}$ & 6 & $0.5 \%$ & & & & 1 & & & & & & & 1 & $1.6 \%$ \\
\hline RCS & 52 & $4.4 \%$ & & & & & 1 & 1 & 1 & & & & 3 & $4.8 \%$ \\
\hline RHR & 138 & $11.7 \%$ & & 2 & 1 & & 1 & 1 & & & & & 5 & $7.9 \%$ \\
\hline SWN & 296 & $25.1 \%$ & 1 & 1 & 1 & 2 & 2 & 1 & 4 & 1 & 1 & & 14 & $22.2 \%$ \\
\hline SWS & 20 & $1.7 \%$ & & & & & & & 2 & 1 & & & 3 & $4.8 \%$ \\
\hline Total & 1180 & $100 \%$ & 5 & 8 & 6 & 5 & 5 & 7 & 13 & 3 & 6 & 5 & 63 & $100 \%$ \\
\hline
\end{tabular}

Table 4. Summary of low-demand AOV failure counts for the FTOP failure mode over time by system.

\begin{tabular}{|c|c|c|c|c|c|c|c|c|c|c|c|c|c|c|}
\hline $\begin{array}{c}\text { System } \\
\text { Code }\end{array}$ & $\begin{array}{l}\text { Valve } \\
\text { Count }\end{array}$ & $\begin{array}{l}\text { Valve } \\
\text { Percent }\end{array}$ & 2005 & 2006 & 2007 & 2008 & 2009 & 2010 & 2011 & 2012 & 2013 & 2014 & Total & $\begin{array}{c}\text { Percent } \\
\text { of } \\
\text { Failures }\end{array}$ \\
\hline AFW & 195 & $20.7 \%$ & & & & & & 1 & & & 3 & 1 & 5 & $33.3 \%$ \\
\hline CCW & 299 & $31.7 \%$ & 1 & & & 1 & 1 & & & & & & 3 & $20.0 \%$ \\
\hline HPI & 70 & $7.4 \%$ & & & & & & & & 1 & & & 1 & $6.7 \%$ \\
\hline ISO & 6 & $0.6 \%$ & & & & & & & & & & & 0 & $0.0 \%$ \\
\hline $\mathrm{RCl}$ & 6 & $0.6 \%$ & & & & & & & & 1 & & & 1 & $6.7 \%$ \\
\hline RCS & 52 & $5.5 \%$ & & & & & & & & & & 1 & 1 & $6.7 \%$ \\
\hline SWN & 296 & $31.4 \%$ & 1 & & & 1 & & & & & & 1 & 3 & $20.0 \%$ \\
\hline SWS & 20 & $2.1 \%$ & & & & & & & 1 & & & & 1 & $6.7 \%$ \\
\hline Total & 944 & $100 \%$ & 2 & 0 & 0 & 2 & 1 & 1 & 1 & 2 & 3 & 3 & 15 & $100 \%$ \\
\hline
\end{tabular}

Table 5. Summary of low-demand AOV failure counts for the SO failure mode over time by system.

\begin{tabular}{|c|c|c|c|c|c|c|c|c|c|c|c|c|c|c|}
\hline $\begin{array}{c}\text { System } \\
\text { Code }\end{array}$ & $\begin{array}{l}\text { Valve } \\
\text { Count }\end{array}$ & $\begin{array}{l}\text { Valve } \\
\text { Percent }\end{array}$ & 2005 & 2006 & 2007 & 2008 & 2009 & 2010 & 2011 & 2012 & 2013 & 2014 & Total & $\begin{array}{c}\text { Percent } \\
\text { of } \\
\text { Failures }\end{array}$ \\
\hline AFW & 195 & $23.2 \%$ & 1 & & 1 & 1 & 1 & & 1 & & & & 5 & $35.7 \%$ \\
\hline CCW & 299 & $35.6 \%$ & & & 1 & & & 1 & 1 & 3 & & & 6 & $42.9 \%$ \\
\hline CRD & 66 & $7.9 \%$ & & & & & & & & & & & 0 & $0.0 \%$ \\
\hline $\mathrm{HPI}$ & 70 & $8.3 \%$ & & & & & & & & & & & 0 & $0.0 \%$ \\
\hline RCS & 52 & $6.2 \%$ & & & & & & & & & & & 0 & $0.0 \%$ \\
\hline RHR & 138 & $16.4 \%$ & & & & 1 & & & & & 1 & & 2 & $14.3 \%$ \\
\hline SWS & 20 & $2.4 \%$ & & & & & & & 1 & & & & 1 & $7.1 \%$ \\
\hline Total & 840 & $100 \%$ & 1 & 0 & 2 & 2 & 1 & 1 & 3 & 3 & 1 & 0 & 14 & $100 \%$ \\
\hline
\end{tabular}


Table 6. Summary of high-demand AOV failure counts for the FTOC failure mode over time by system.

\begin{tabular}{|c|c|c|c|c|c|c|c|c|c|c|c|c|c|c|}
\hline $\begin{array}{c}\text { System } \\
\text { Code }\end{array}$ & $\begin{array}{l}\text { Valve } \\
\text { Count }\end{array}$ & $\begin{array}{c}\text { Valve } \\
\text { Percent }\end{array}$ & 2005 & 2006 & 2007 & 2008 & 2009 & 2010 & 2011 & 2012 & 2013 & 2014 & Total & $\begin{array}{c}\text { Percent } \\
\text { of } \\
\text { Failures }\end{array}$ \\
\hline AFW & 165 & $20.6 \%$ & 3 & 5 & & 3 & & 1 & 2 & 2 & 3 & 7 & 26 & $37.1 \%$ \\
\hline CCW & 141 & $17.6 \%$ & & 1 & & & & 1 & & 1 & 1 & & 4 & $5.7 \%$ \\
\hline CRD & 51 & $6.4 \%$ & & & & & & & & & 1 & & 1 & $1.4 \%$ \\
\hline RCS & 61 & $7.6 \%$ & 1 & & 1 & & & 2 & & & & & 4 & $5.7 \%$ \\
\hline RHR & 134 & $16.7 \%$ & & 1 & 1 & 1 & 2 & 2 & 2 & & 1 & 1 & 11 & $15.7 \%$ \\
\hline SWN & 215 & $26.8 \%$ & 2 & 2 & & 4 & 5 & 2 & 3 & & 1 & 5 & 24 & $34.3 \%$ \\
\hline SWS & 35 & $4.4 \%$ & & & & & & & & & & & 0 & $0.0 \%$ \\
\hline Total & 802 & $100 \%$ & 6 & 9 & 2 & 8 & 7 & 8 & 7 & 3 & 7 & 13 & 70 & $100 \%$ \\
\hline
\end{tabular}

Table 7. Summary of high-demand AOV failure counts for the FTOP failure mode over time by system.

\begin{tabular}{|c|c|c|c|c|c|c|c|c|c|c|c|c|c|c|}
\hline $\begin{array}{c}\text { System } \\
\text { Code }\end{array}$ & $\begin{array}{l}\text { Valve } \\
\text { Count }\end{array}$ & $\begin{array}{l}\text { Valve } \\
\text { Percent }\end{array}$ & 2005 & 2006 & 2007 & 2008 & 2009 & 2010 & 2011 & 2012 & 2013 & 2014 & Total & $\begin{array}{c}\text { Percent } \\
\text { of } \\
\text { Failures }\end{array}$ \\
\hline AFW & 165 & $21.5 \%$ & & & 1 & & & & 1 & & 3 & 1 & 6 & $21.4 \%$ \\
\hline CCW & 141 & $18.4 \%$ & & & & 1 & & & & & 1 & & 2 & $7.1 \%$ \\
\hline CRD & 51 & $6.6 \%$ & & & & & & & & & 1 & & 1 & $3.6 \%$ \\
\hline RCS & 61 & $8.0 \%$ & & & & & & & & & & & & $0.0 \%$ \\
\hline RHR & 134 & $17.5 \%$ & & & & 1 & & & & 2 & & 1 & 4 & $14.3 \%$ \\
\hline SWN & 215 & $28.0 \%$ & 4 & & 1 & 1 & 2 & 3 & 1 & 1 & & 2 & 15 & $53.6 \%$ \\
\hline Total & 767 & $100 \%$ & 4 & 0 & 2 & 3 & 2 & 3 & 2 & 3 & 5 & 4 & 28 & $100 \%$ \\
\hline
\end{tabular}

Table 8. Summary of high-demand AOV failure counts for the SO failure mode over time by system.

\begin{tabular}{|c|c|c|c|c|c|c|c|c|c|c|c|c|c|c|}
\hline $\begin{array}{c}\text { System } \\
\text { Code }\end{array}$ & $\begin{array}{l}\text { Valve } \\
\text { Count }\end{array}$ & $\begin{array}{c}\text { Valve } \\
\text { Percent }\end{array}$ & 2005 & 2006 & 2007 & 2008 & 2009 & 2010 & 2011 & 2012 & 2013 & 2014 & Total & $\begin{array}{c}\text { Percent } \\
\text { of } \\
\text { Failures }\end{array}$ \\
\hline AFW & 165 & $25.1 \%$ & 1 & & & & & 1 & & 1 & & & 3 & $33.3 \%$ \\
\hline CCW & 141 & $21.5 \%$ & & & & & & & & 1 & & & 1 & $11.1 \%$ \\
\hline $\mathrm{RCl}$ & 2 & $0.3 \%$ & & & & 1 & & & & & & & 1 & $11.1 \%$ \\
\hline RHR & 134 & $20.4 \%$ & & & & 1 & & & & & & & 1 & $11.1 \%$ \\
\hline SWN & 215 & $32.7 \%$ & & 1 & & & 2 & & & & & & 3 & $33.3 \%$ \\
\hline Total & 657 & $100 \%$ & 1 & 1 & 0 & 2 & 2 & 1 & 0 & 2 & 0 & 0 & 9 & $100 \%$ \\
\hline
\end{tabular}




\subsection{AOV Engineering Analysis by Failure Modes}

The engineering analysis of AOV failure sub-components, causes, detection methods, and recoverability are presented in this section. Each analysis first divides the events into two categories: low-demand AOVs (with less than or equal to 20 demands/year) and high-demand AOVs (with greater than 20 demands/year).

The second division of the events is by the failure mode determined after ICES data review by the staff. See Section 5 for more description of failure modes.

AOV sub-component contributions to the three failure modes are presented in Figure 15. The subcomponent contributions are similar to those used in the CCF database. For all three failure modes, the actuator is the largest contributor to the failure rates/probabilities.

AOV cause group contributions to the three failure modes are presented in Figure 16. The cause groups are similar to those used in the CCF database. Table 9 shows the breakdown of the cause groups with the specific causes that were coded during the data collection. The most likely cause for the FTOC and FTOP failure modes is grouped as Internal. Internal means that the cause was related to something within the AOV component such as a worn out part or the normal internal environment. The second most likely cause for the FTOC and FTOP failure mode is grouped as Human, which includes human action, procedures and maintenance. The most likely cause for the SO failure mode is either Design or Internal, closely followed by Human

AOV detection methods to the three failure modes are presented in Figure 17. Note that there are differences between the low-demand and high-demand detection methods.

Low-Demand - the most likely detection method for FTOC is a testing demand. The most likely detection method for FTOP and SO is an actual demand.

High-Demand - the most likely detection method for FTOC is a non-test demand followed by testing. The most likely detection method for FTOP and SO is an actual demand.

AOV failure recoverability determination for three failure modes is presented in Figure 18. AOV failures are, by better than a 5:1 ratio, considered not recoverable. 
Table 9. Component failure cause groups.

\begin{tabular}{|c|c|c|}
\hline Group & Specific Cause & Description \\
\hline \multirow[t]{3}{*}{ Design } & $\begin{array}{l}\text { Construction/installation } \\
\text { error or inadequacy }\end{array}$ & $\begin{array}{l}\text { Used when a construction or installation error is made during } \\
\text { the original or modification installation. This includes } \\
\text { specification of incorrect component or material. }\end{array}$ \\
\hline & Design error or inadequacy & Used when a design error is made. \\
\hline & $\begin{array}{l}\text { Manufacturing error or } \\
\text { inadequacy }\end{array}$ & $\begin{array}{l}\text { Used when a manufacturing error is made during component } \\
\text { manufacture. }\end{array}$ \\
\hline \multirow[t]{2}{*}{ External } & State of other component & $\begin{array}{l}\text { Used when the cause of a failure is the result of a component } \\
\text { state that is not associated with the component that failed. } \\
\text { An example would be the diesel failed due to no fuel in the } \\
\text { fuel storage tanks. }\end{array}$ \\
\hline & $\begin{array}{l}\text { Ambient environmental } \\
\text { stress }\end{array}$ & $\begin{array}{l}\text { Used when the cause of a failure is the result of an } \\
\text { environmental condition from the location of the component. }\end{array}$ \\
\hline \multirow[t]{3}{*}{ Human } & $\begin{array}{l}\text { Accidental action } \\
\text { (unintentional or undesired } \\
\text { human errors) }\end{array}$ & $\begin{array}{l}\text { Used when a human error (during the performance of an } \\
\text { activity) results in an unintentional or undesired action. }\end{array}$ \\
\hline & Human action procedure & $\begin{array}{l}\text { Used when the procedure is not followed or the procedure is } \\
\text { incorrect. For example: when a missed step or incorrect step } \\
\text { in a surveillance procedure results in a component failure. }\end{array}$ \\
\hline & Inadequate maintenance & $\begin{array}{l}\text { Used when a human error (during the performance of } \\
\text { maintenance) results in an unintentional or undesired action. }\end{array}$ \\
\hline \multirow[t]{4}{*}{ Internal } & $\begin{array}{l}\text { Internal to component, } \\
\text { piece-part }\end{array}$ & $\begin{array}{l}\text { Used when the cause of a failure is a non-specific result of a } \\
\text { failure internal to the component that failed other than aging } \\
\text { or wear. }\end{array}$ \\
\hline & Internal environment & $\begin{array}{l}\text { The internal environment led to the failure. Debris/Foreign } \\
\text { material as well as an operating medium chemistry issue. }\end{array}$ \\
\hline & Setpoint drift & $\begin{array}{l}\text { Used when the cause of a failure is the result of setpoint drift } \\
\text { or adjustment. }\end{array}$ \\
\hline & Age/Wear & $\begin{array}{l}\text { Used when the cause of the failure is a non-specific aging or } \\
\text { wear issue. }\end{array}$ \\
\hline \multirow[t]{2}{*}{ Other } & Unknown & Used when the cause of the failure is not known. \\
\hline & $\begin{array}{l}\text { Other (stated cause does } \\
\text { not fit other categories) }\end{array}$ & $\begin{array}{l}\text { Used when the cause of a failure is provided but it does not } \\
\text { meet any one of the descriptions. }\end{array}$ \\
\hline Procedure & Inadequate procedure & $\begin{array}{l}\text { Used when the cause of a failure is the result of an } \\
\text { inadequate procedure operating or maintenance. }\end{array}$ \\
\hline
\end{tabular}



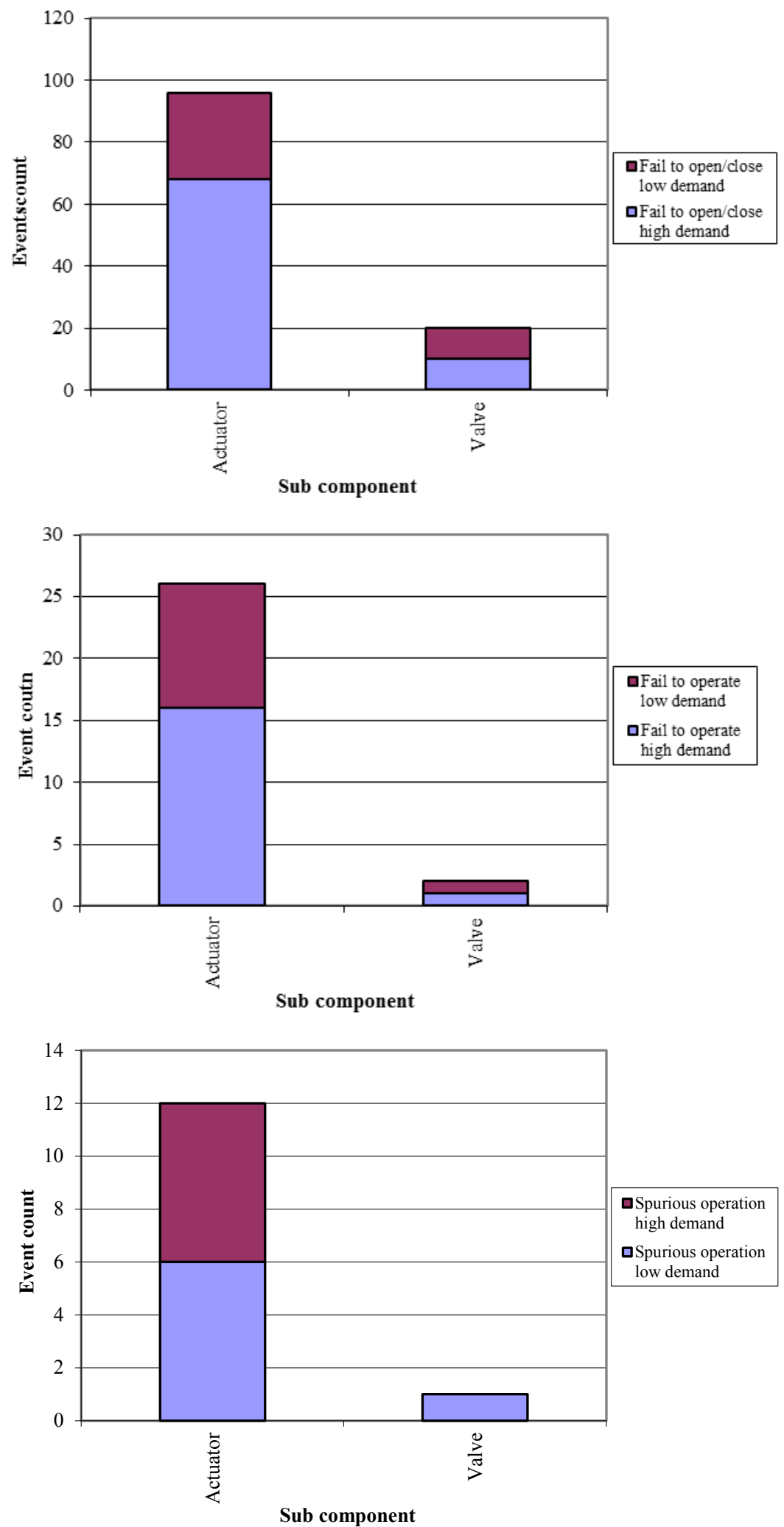

Figure 15. AOV failure event breakdown by subcomponent, failure mode, and demand rate 


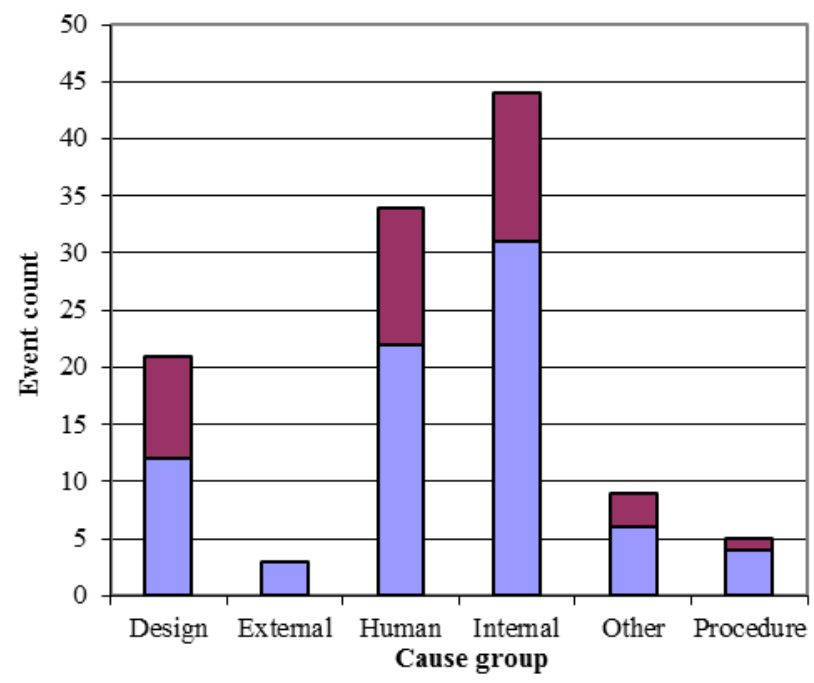

aFail to open/close low demand

a Fail to open/close high demand

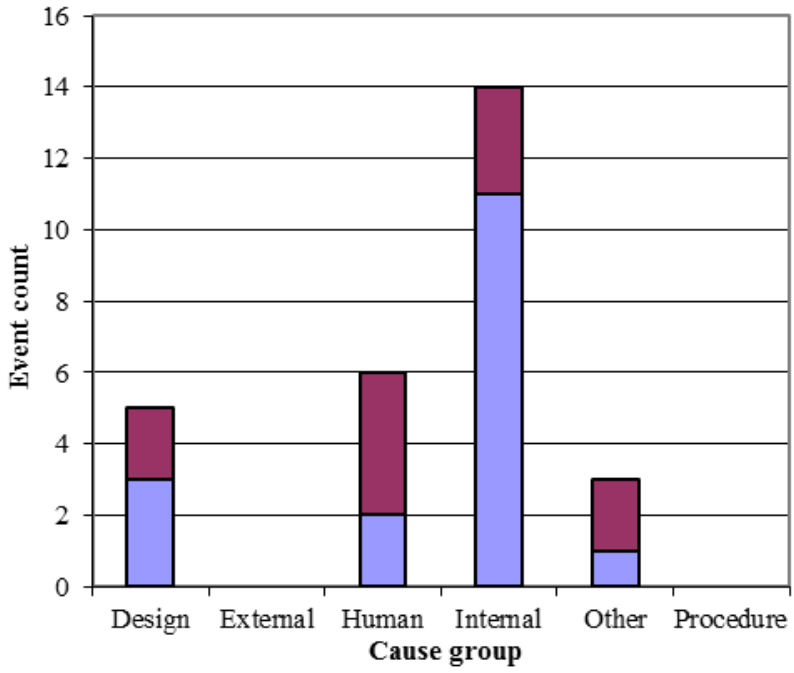

QFail to operate low demand

口Fail to operate high demand

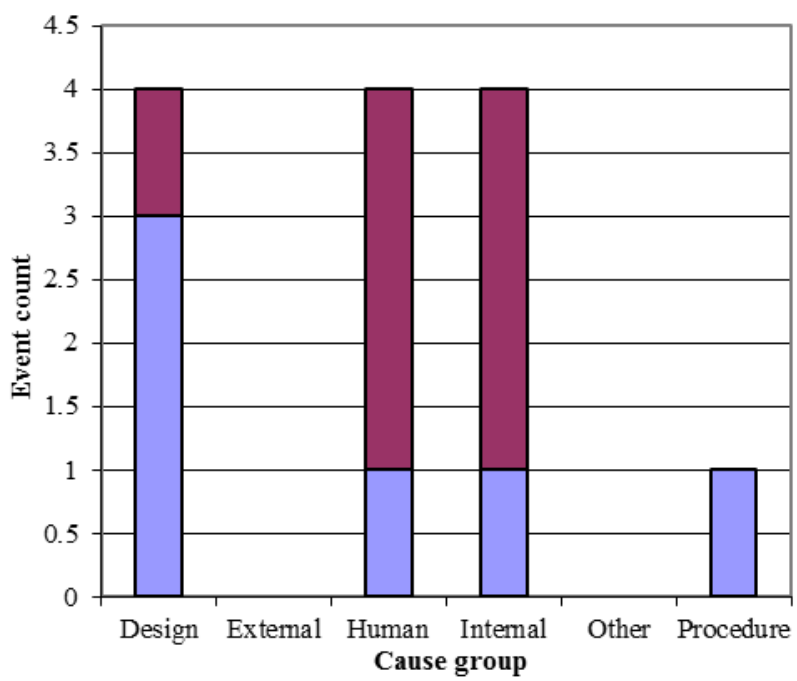

- Spurious operation low demand

口Spurious operation high demand

Figure 16. AOV failure event breakdown by cause group, failure mode, and demand rate 

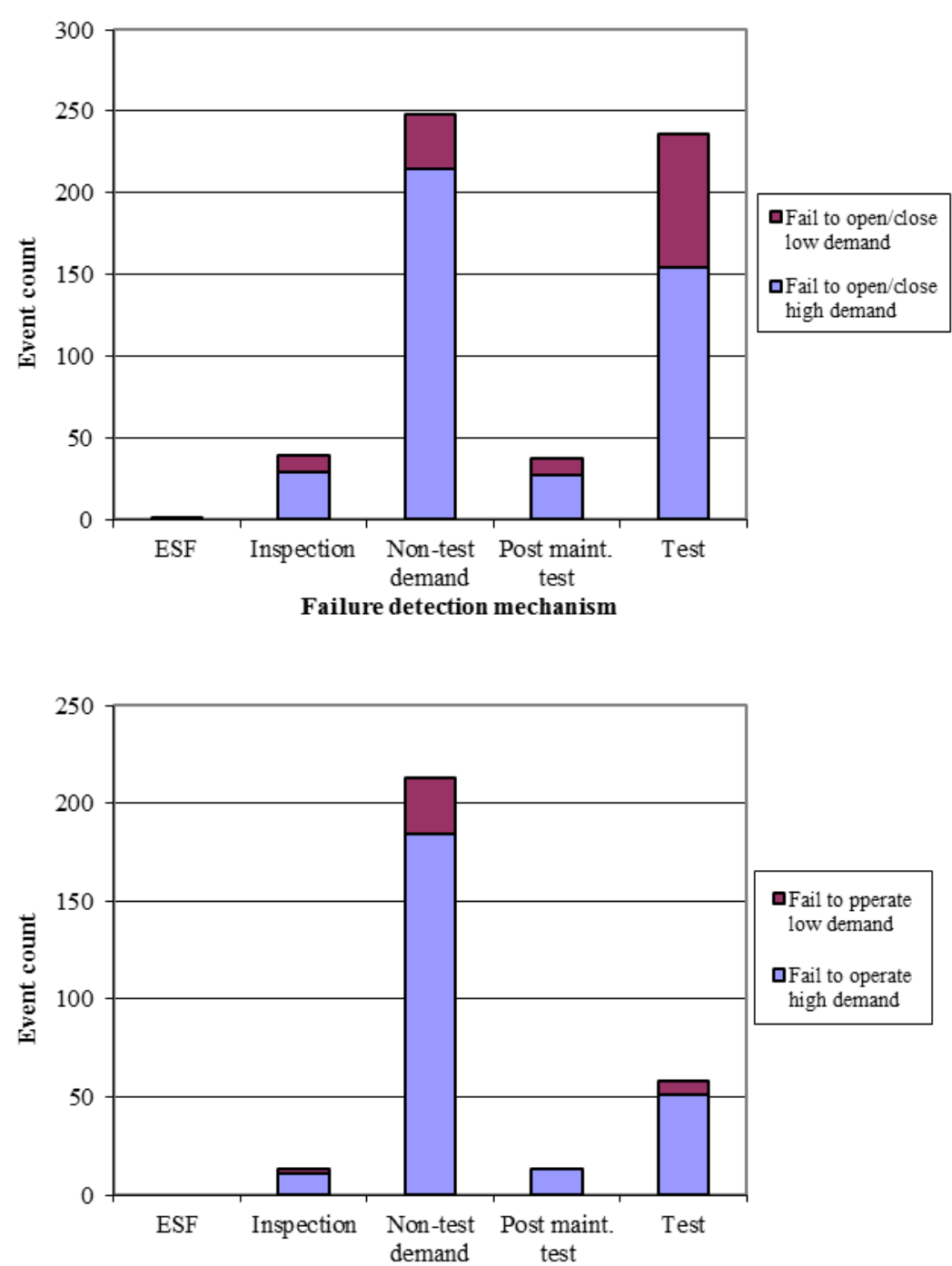

Failure detection mechanism

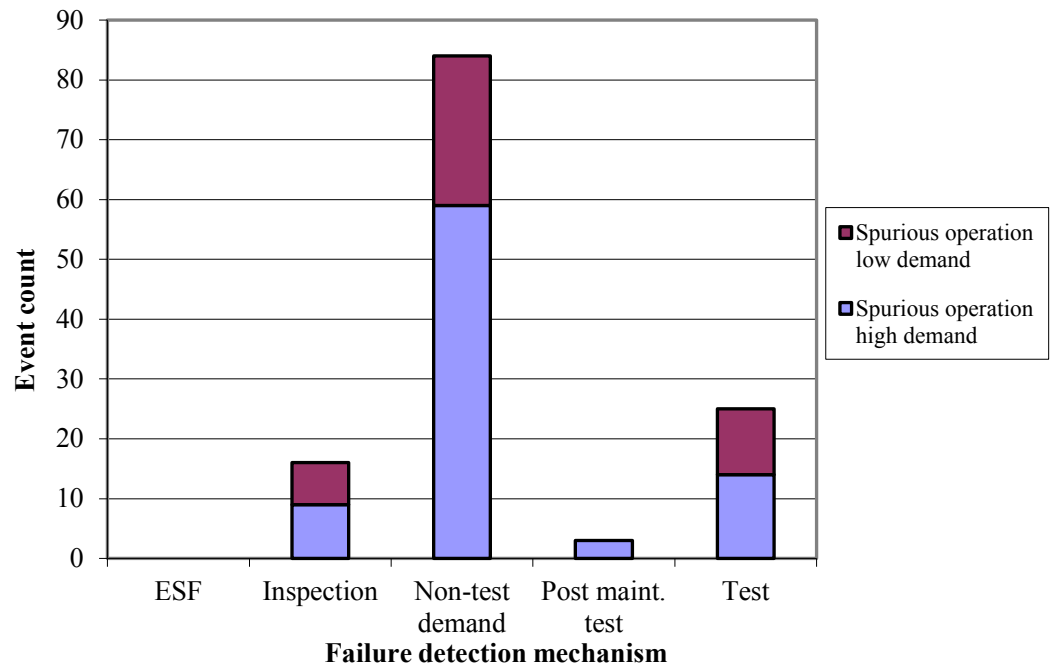

Figure 17. AOV failure event breakdown by method of detection, failure mode, and demand rate 

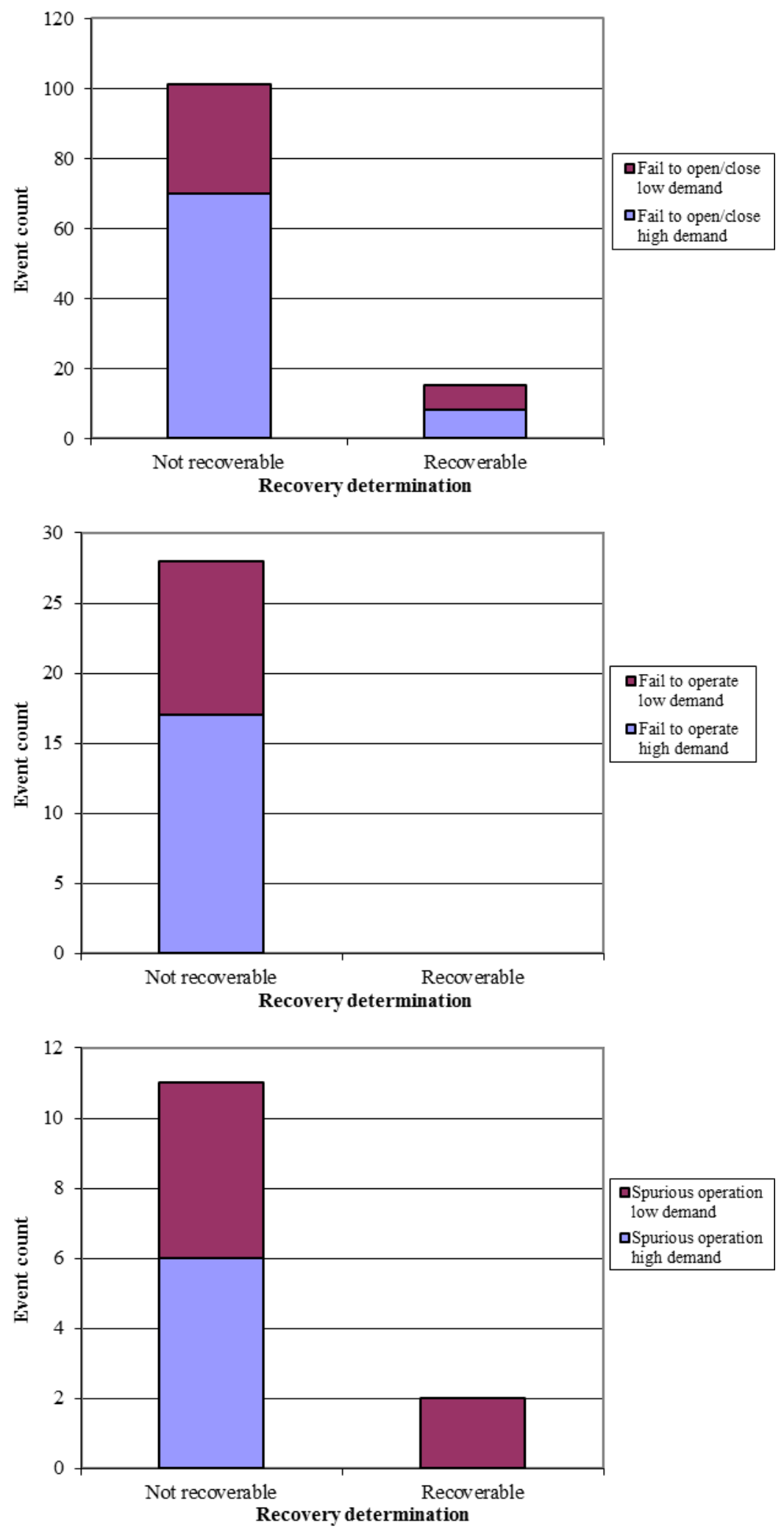

Figure 18. AOV failure event breakdown by recoverability, failure mode, and demand rate 
Enhanced Component Performance Study 


\section{AOV ASSEMBLY DESCRIPTION}

An AOV assembly consists of a valve body and pneumatic operator sub-components. The valve body is generally a globe or butterfly type. The pneumatic operator is generally a piston or diaphragm type actuator. Main steam isolation valves and power operated relief valves are excluded from the AOV study even though pneumatically operated, as these are valves with different design and operating features.

The piece-parts of the valve body are the stem, packing, and internals. The pneumatic operator pieceparts may include piston internals/seals or diaphragm, positioner, mechanical linkage, volume booster, pilot valve, bolting, air regulator, airline, and wiring/contacts. Failures associated with instrument air systems that are not integral to the AOV assembly (e.g., contamination from the instrument air system that failed the AOV) are excluded in the AOV analysis.

Failure modes for the AOV include FTOC, which combines the fail to open and fail to close failure modes into a single category; FTOP, which is a rate-based failure mode that includes fail to control for a flow/temperature control device and any other rate-based failure modes not including spurious operation; and SO, which includes spurious opening and spurious closing. 


\section{DATA TABLES}

Table 10. Plot data for Figure 1, failure probability estimate trend for AOV FTOC, all systems, industrywide trend of low-demand AOVs.

\begin{tabular}{|c|c|c|c|c|c|c|c|c|}
\hline \multirow[b]{2}{*}{$\begin{array}{c}\text { FYI } \\
\text { Source }\end{array}$} & \multirow[b]{2}{*}{ Failures } & \multirow[b]{2}{*}{ Demands } & \multicolumn{3}{|c|}{ Regression Curve Data Points } & \multicolumn{3}{|c|}{ Yearly Estimate Data Points } \\
\hline & & & Mean & $\begin{array}{c}\text { Lower } \\
\mathbf{( 5 \% )}\end{array}$ & $\begin{array}{l}\text { Upper } \\
(95 \%)\end{array}$ & $\begin{array}{c}\text { Lower } \\
(5 \%)\end{array}$ & $\begin{array}{l}\text { Upper } \\
(95 \%) \\
\end{array}$ & Mean \\
\hline \multicolumn{2}{|c|}{2010 Update } & & & & & 6.27E-05 & $2.74 \mathrm{E}-03$ & 9.51E-04 \\
\hline 1998 & 10 & $8,445.4$ & & & & $6.38 \mathrm{E}-04$ & 1.93E-03 & 1.16E-03 \\
\hline 1999 & 7 & $8,800.0$ & & & & 3.84E-04 & 1.46E-03 & 7.94E-04 \\
\hline 2000 & 4 & $8,454.1$ & & & & 1.83E-04 & $1.08 \mathrm{E}-03$ & 4.95E-04 \\
\hline 2001 & 8 & $8,637.8$ & & & & 4.67E-04 & $1.62 E-03$ & $9.16 \mathrm{E}-04$ \\
\hline 2002 & 7 & $8,854.0$ & & & & 3.82E-04 & $1.45 \mathrm{E}-03$ & 7.90E-04 \\
\hline 2003 & 9 & $8,689.5$ & & & & 5.42E-04 & $1.75 \mathrm{E}-03$ & $1.02 E-03$ \\
\hline 2004 & 6 & $8,806.2$ & & & & 3.12E-04 & 1.32E-03 & $6.88 \mathrm{E}-04$ \\
\hline 2005 & 5 & $8,807.1$ & 7.46E-04 & 4.33E-04 & $1.29 \mathrm{E}-03$ & $2.42 \mathrm{E}-04$ & $1.18 \mathrm{E}-03$ & $5.82 \mathrm{E}-04$ \\
\hline 2006 & 8 & $8,101.2$ & 7.41E-04 & 4.67E-04 & 1.18E-03 & 4.96E-04 & $1.72 \mathrm{E}-03$ & $9.72 \mathrm{E}-04$ \\
\hline 2007 & 6 & $8,158.5$ & 7.36E-04 & 4.99E-04 & 1.09E-03 & 3.35E-04 & 1.42E-03 & 7.38E-04 \\
\hline 2008 & 5 & $8,097.7$ & 7.31E-04 & 5.25E-04 & 1.02E-03 & 2.62E-04 & $1.28 \mathrm{E}-03$ & $6.29 E-04$ \\
\hline 2009 & 5 & $8,033.3$ & 7.26E-04 & 5.38E-04 & 9.81E-04 & 2.64E-04 & $1.29 \mathrm{E}-03$ & 6.34E-04 \\
\hline 2010 & 7 & $8,187.1$ & 7.21E-04 & 5.32E-04 & 9.77E-04 & 4.11E-04 & 1.56E-03 & 8.49E-04 \\
\hline 2011 & 13 & $8,081.7$ & 7.16E-04 & 5.10E-04 & 1.01E-03 & 9.26E-04 & 2.44E-03 & $1.55 \mathrm{E}-03$ \\
\hline 2012 & 3 & $8,170.3$ & 7.11E-04 & 4.77E-04 & 1.06E-03 & 1.23E-04 & 9.59E-04 & 3.97E-04 \\
\hline 2013 & 6 & $8,237.0$ & 7.06E-04 & 4.40E-04 & 1.13E-03 & 3.32E-04 & 1.41E-03 & 7.32E-04 \\
\hline 2014 & 5 & $8,056.4$ & 7.02E-04 & 4.02E-04 & 1.23E-03 & 2.63E-04 & $1.28 \mathrm{E}-03$ & 6.32E-04 \\
\hline Total & 114 & $142,617.1$ & & & & & & \\
\hline
\end{tabular}


Table 11. Plot data for Figure 2, failure probability estimate trend for AOV FTOC, all systems, industrywide trend of high-demand AOVs.

\begin{tabular}{|c|c|c|c|c|c|c|c|c|}
\hline \multirow[b]{2}{*}{$\begin{array}{c}\text { FYI } \\
\text { Source }\end{array}$} & \multirow[b]{2}{*}{ Failures } & \multirow[b]{2}{*}{ Demands } & \multicolumn{3}{|c|}{ Regression Curve Data Points } & \multicolumn{3}{|c|}{ Plot Trend Error Bar Points } \\
\hline & & & Mean & $\begin{array}{c}\text { Lower } \\
(5 \%)\end{array}$ & $\begin{array}{l}\text { Upper } \\
(95 \%)\end{array}$ & $\begin{array}{l}\text { Lower } \\
(5 \%)\end{array}$ & $\begin{array}{l}\text { Upper } \\
(95 \%)\end{array}$ & Mean \\
\hline \multicolumn{2}{|c|}{2010 Update } & & & & & 6.27E-05 & 2.74E-03 & $9.51 \mathrm{E}-04$ \\
\hline 1998 & 12 & $26,740.9$ & & & & $2.55 E-04$ & 7.00E-04 & 4.36E-04 \\
\hline 1999 & 11 & $28,609.0$ & & & & 2.14E-04 & 6.16E-04 & 3.77E-04 \\
\hline 2000 & 8 & $28,062.2$ & & & & $1.45 \mathrm{E}-04$ & 5.03E-04 & 2.83E-04 \\
\hline 2001 & 11 & $27,407.8$ & & & & 2.23E-04 & $6.42 \mathrm{E}-04$ & 3.92E-04 \\
\hline 2002 & 5 & $27,548.0$ & & & & 7.76E-05 & 3.79E-04 & 1.87E-04 \\
\hline 2003 & 7 & $28,041.7$ & & & & $1.21 \mathrm{E}-04$ & 4.60E-04 & 2.50E-04 \\
\hline 2004 & 8 & $27,442.5$ & & & & $1.48 \mathrm{E}-04$ & 5.13E-04 & 2.89E-04 \\
\hline 2005 & 6 & $27,541.2$ & $1.90 \mathrm{E}-04$ & $8.74 \mathrm{E}-05$ & 4.12E-04 & $1.00 \mathrm{E}-04$ & 4.24E-04 & $2.21 \mathrm{E}-04$ \\
\hline 2006 & 9 & $27,408.2$ & 1.99E-04 & 1.03E-04 & 3.84E-04 & 1.72E-04 & 5.57E-04 & 3.24E-04 \\
\hline 2007 & 2 & $27,871.4$ & 2.08E-04 & $1.20 \mathrm{E}-04$ & 3.63E-04 & 1.92E-05 & 2.36E-04 & 8.39E-05 \\
\hline 2008 & 8 & $27,770.1$ & 2.19E-04 & 1.37E-04 & 3.49E-04 & 1.46E-04 & 5.07E-04 & 2.86E-04 \\
\hline 2009 & 7 & $27,127.3$ & 2.29E-04 & $1.52 \mathrm{E}-04$ & 3.46E-04 & $1.25 \mathrm{E}-04$ & 4.75E-04 & $2.58 \mathrm{E}-04$ \\
\hline 2010 & 8 & $27,074.6$ & 2.40E-04 & 1.61E-04 & 3.58E-04 & $1.50 \mathrm{E}-04$ & 5.20E-04 & 2.93E-04 \\
\hline 2011 & 7 & $27,056.2$ & 2.52E-04 & 1.63E-04 & 3.89E-04 & 1.25E-04 & 4.76E-04 & $2.59 \mathrm{E}-04$ \\
\hline 2012 & 3 & $26,691.7$ & 2.64E-04 & $1.59 \mathrm{E}-04$ & 4.37E-04 & 3.79E-05 & 2.96E-04 & $1.22 \mathrm{E}-04$ \\
\hline 2013 & 7 & $26,675.4$ & 2.77E-04 & $1.52 \mathrm{E}-04$ & 5.05E-04 & 1.27E-04 & 4.82E-04 & $2.62 \mathrm{E}-04$ \\
\hline 2014 & 13 & $26,529.7$ & 2.90E-04 & 1.42E-04 & 5.91E-04 & 2.84E-04 & 7.48E-04 & 4.74E-04 \\
\hline Total & 132 & $465,598.1$ & & & & & & \\
\hline
\end{tabular}


Table 12. Plot data for Figure 3, failure rate estimate trend for AOV FTOP, all systems, industry-wide trend of low-demand AOVs.

\begin{tabular}{|c|c|c|c|c|c|c|c|c|}
\hline \multirow[b]{2}{*}{$\begin{array}{c}\text { FYI } \\
\text { Source }\end{array}$} & \multirow[b]{2}{*}{ Failures } & \multirow[b]{2}{*}{ Hours } & \multicolumn{3}{|c|}{ Regression Curve Data Points } & \multicolumn{3}{|c|}{ Yearly Estimate Data Points } \\
\hline & & & Mean & $\begin{array}{c}\text { Lower } \\
(5 \%)\end{array}$ & $\begin{array}{l}\text { Upper } \\
(95 \%)\end{array}$ & $\begin{array}{c}\text { Lower } \\
(5 \%)\end{array}$ & $\begin{array}{l}\text { Upper } \\
(95 \%)\end{array}$ & Mean \\
\hline \multicolumn{2}{|c|}{2010 Update } & & & & & 2.66E-08 & $6.59 \mathrm{E}-07$ & 2.49E-07 \\
\hline 1998 & 0 & $10,617,120.0$ & & & & $1.40 \mathrm{E}-10$ & 2.77E-07 & 3.55E-08 \\
\hline 1999 & 3 & $10,590,840.0$ & & & & 7.71E-08 & $6.02 \mathrm{E}-07$ & $2.49 \mathrm{E}-07$ \\
\hline 2000 & 1 & $10,634,640.0$ & & & & $1.25 \mathrm{E}-08$ & 3.93E-07 & 1.06E-07 \\
\hline 2001 & 3 & $10,687,200.0$ & & & & 7.66E-08 & $5.98 \mathrm{E}-07$ & 2.47E-07 \\
\hline 2002 & 2 & $10,687,200.0$ & & & & 4.05E-08 & 4.97E-07 & 1.77E-07 \\
\hline 2003 & 1 & $10,695,960.0$ & & & & $1.24 \mathrm{E}-08$ & $3.91 \mathrm{E}-07$ & 1.06E-07 \\
\hline 2004 & 0 & $10,704,720.0$ & & & & $1.39 \mathrm{E}-10$ & 2.76E-07 & 3.53E-08 \\
\hline 2005 & 2 & $10,704,720.0$ & $6.05 E-08$ & 2.53E-08 & $1.45 \mathrm{E}-07$ & 4.04E-08 & 4.96E-07 & 1.76E-07 \\
\hline 2006 & 0 & $10,766,040.0$ & 7.01E-08 & 3.32E-08 & $1.48 \mathrm{E}-07$ & $1.38 \mathrm{E}-10$ & 2.75E-07 & $3.51 \mathrm{E}-08$ \\
\hline 2007 & 0 & $10,695,960.0$ & 8.13E-08 & 4.33E-08 & 1.53E-07 & $1.39 \mathrm{E}-10$ & 2.76E-07 & 3.53E-08 \\
\hline 2008 & 2 & $10,704,720.0$ & $9.42 E-08$ & 5.54E-08 & $1.60 \mathrm{E}-07$ & 4.04E-08 & 4.96E-07 & 1.76E-07 \\
\hline 2009 & 1 & $10,687,200.0$ & 1.09E-07 & 6.88E-08 & 1.73E-07 & $1.24 \mathrm{E}-08$ & 3.91E-07 & 1.06E-07 \\
\hline 2010 & 1 & $10,687,200.0$ & 1.27E-07 & 8.20E-08 & 1.95E-07 & $1.24 \mathrm{E}-08$ & $3.91 \mathrm{E}-07$ & 1.06E-07 \\
\hline 2011 & 1 & $10,844,880.0$ & 1.47E-07 & $9.28 \mathrm{E}-08$ & 2.32E-07 & 1.23E-08 & 3.87E-07 & 1.05E-07 \\
\hline 2012 & 2 & $10,748,520.0$ & $1.70 \mathrm{E}-07$ & $1.00 \mathrm{E}-07$ & 2.88E-07 & 4.03E-08 & 4.95E-07 & 1.76E-07 \\
\hline 2013 & 3 & $10,766,040.0$ & 1.97E-07 & 1.06E-07 & 3.68E-07 & 7.62E-08 & 5.94E-07 & 2.46E-07 \\
\hline 2014 & 3 & $10,757,280.0$ & $2.28 \mathrm{E}-07$ & $1.09 \mathrm{E}-07$ & 4.78E-07 & 7.62E-08 & 5.95E-07 & 2.46E-07 \\
\hline Total & 25 & $181,980,240.0$ & & & & & & \\
\hline
\end{tabular}


Table 13. Plot data for Figure 4, failure rate estimate trend for AOV FTOP, all systems, industry-wide trend of high-demand AOVs.

\begin{tabular}{|c|c|c|c|c|c|c|c|c|}
\hline \multirow[b]{2}{*}{$\begin{array}{c}\text { FYI } \\
\text { Source }\end{array}$} & \multirow[b]{2}{*}{ Failures } & \multirow[b]{2}{*}{ Hours } & \multicolumn{3}{|c|}{ Regression Curve Data Points } & \multicolumn{3}{|c|}{ Yearly Estimate Data Points } \\
\hline & & & Mean & $\begin{array}{c}\text { Lower } \\
(5 \%)\end{array}$ & $\begin{array}{l}\text { Upper } \\
(95 \%)\end{array}$ & $\begin{array}{c}\text { Lower } \\
(5 \%)\end{array}$ & $\begin{array}{l}\text { Upper } \\
(95 \%)\end{array}$ & Mean \\
\hline \multicolumn{2}{|c|}{2010 Update } & & & & & 2.66E-08 & $6.59 \mathrm{E}-07$ & 2.49E-07 \\
\hline 1998 & 3 & $7,568,640.0$ & & & & $1.22 \mathrm{E}-07$ & $9.53 \mathrm{E}-07$ & 3.94E-07 \\
\hline 1999 & 3 & $7,594,920.0$ & & & & $1.22 \mathrm{E}-07$ & $9.51 \mathrm{E}-07$ & 3.93E-07 \\
\hline 2000 & 6 & $7,612,440.0$ & & & & 3.30E-07 & 1.40E-06 & 7.29E-07 \\
\hline 2001 & 2 & $7,516,080.0$ & & & & $6.49 \mathrm{E}-08$ & 7.97E-07 & 2.83E-07 \\
\hline 2002 & 2 & $7,568,640.0$ & & & & $6.46 \mathrm{E}-08$ & 7.93E-07 & 2.82E-07 \\
\hline 2003 & 3 & $7,533,600.0$ & & & & $1.23 E-07$ & 9.57E-07 & 3.96E-07 \\
\hline 2004 & 2 & $7,533,600.0$ & & & & $6.48 \mathrm{E}-08$ & 7.96E-07 & 2.83E-07 \\
\hline 2005 & 4 & $7,542,360.0$ & $1.95 \mathrm{E}-07$ & 8.03E-08 & 4.75E-07 & $1.88 \mathrm{E}-07$ & 1.11E-06 & 5.09E-07 \\
\hline 2006 & 0 & $7,507,320.0$ & 2.19E-07 & 1.03E-07 & 4.68E-07 & $2.23 E-10$ & 4.43E-07 & 5.67E-08 \\
\hline 2007 & 2 & $7,507,320.0$ & $2.46 \mathrm{E}-07$ & $1.30 \mathrm{E}-07$ & 4.67E-07 & $6.50 \mathrm{E}-08$ & 7.98E-07 & 2.84E-07 \\
\hline 2008 & 3 & $7,524,840.0$ & 2.76E-07 & 1.61E-07 & 4.73E-07 & 1.23E-07 & 9.58E-07 & 3.96E-07 \\
\hline 2009 & 2 & $7,507,320.0$ & $3.10 \mathrm{E}-07$ & $1.95 \mathrm{E}-07$ & 4.93E-07 & $6.50 \mathrm{E}-08$ & 7.98E-07 & 2.84E-07 \\
\hline 2010 & 3 & $7,410,960.0$ & 3.47E-07 & $2.25 \mathrm{E}-07$ & 5.36E-07 & $1.24 \mathrm{E}-07$ & 9.71E-07 & 4.02E-07 \\
\hline 2011 & 2 & $7,428,480.0$ & 3.90E-07 & 2.47E-07 & $6.14 \mathrm{E}-07$ & 6.56E-08 & 8.05E-07 & 2.86E-07 \\
\hline 2012 & 3 & $7,314,600.0$ & 4.37E-07 & 2.60E-07 & 7.37E-07 & $1.26 \mathrm{E}-07$ & $9.82 \mathrm{E}-07$ & 4.06E-07 \\
\hline 2013 & 5 & $7,297,080.0$ & 4.91E-07 & 2.64E-07 & $9.11 \mathrm{E}-07$ & 2.66E-07 & 1.30E-06 & 6.39E-07 \\
\hline 2014 & 4 & $7,279,560.0$ & $5.51 \mathrm{E}-07$ & 2.64E-07 & 1.15E-06 & $1.94 \mathrm{E}-07$ & 1.15E-06 & 5.24E-07 \\
\hline Total & 49 & $127,247,760.0$ & & & & & & \\
\hline
\end{tabular}


Table 14. Plot data for Figure 5, failure rate estimate trend for AOV SO, all systems, industry-wide trend of low-demand AOVs.

\begin{tabular}{|c|c|c|c|c|c|c|c|c|}
\hline \multirow[b]{2}{*}{$\begin{array}{c}\text { FYI } \\
\text { Source }\end{array}$} & \multirow[b]{2}{*}{ Failures } & \multirow[b]{2}{*}{ Hours } & \multicolumn{3}{|c|}{ Regression Curve Data Points } & \multicolumn{3}{|c|}{ Yearly Estimate Data Points } \\
\hline & & & Mean & $\begin{array}{c}\text { Lower } \\
\text { (5\%) }\end{array}$ & $\begin{array}{l}\text { Upper } \\
(95 \%)\end{array}$ & $\begin{array}{c}\text { Lower } \\
(5 \%)\end{array}$ & $\begin{array}{l}\text { Upper } \\
(95 \%)\end{array}$ & Mean \\
\hline \multicolumn{2}{|c|}{2010 Update } & & & & & 2.04E-09 & 4.49E-07 & $1.31 \mathrm{E}-07$ \\
\hline 1998 & 0 & $10,617,120.0$ & & & & $1.37 \mathrm{E}-10$ & 2.73E-07 & $3.49 \mathrm{E}-08$ \\
\hline 1999 & 6 & $10,590,840.0$ & & & & 2.06E-07 & 8.74E-07 & $4.55 \mathrm{E}-07$ \\
\hline 2000 & 1 & $10,634,640.0$ & & & & $1.23 E-08$ & 3.86E-07 & 1.05E-07 \\
\hline 2001 & 1 & $10,687,200.0$ & & & & $1.22 \mathrm{E}-08$ & 3.85E-07 & 1.04E-07 \\
\hline 2002 & 8 & $10,687,200.0$ & & & & 3.01E-07 & 1.05E-06 & 5.91E-07 \\
\hline 2003 & 2 & $10,695,960.0$ & & & & $3.98 E-08$ & 4.88E-07 & $1.74 \mathrm{E}-07$ \\
\hline 2004 & 1 & $10,704,720.0$ & & & & $1.22 \mathrm{E}-08$ & 3.84E-07 & 1.04E-07 \\
\hline 2005 & 1 & $10,704,720.0$ & $1.08 \mathrm{E}-07$ & 3.67E-08 & $3.20 \mathrm{E}-07$ & $1.22 E-08$ & 3.84E-07 & 1.04E-07 \\
\hline 2006 & 0 & $10,766,040.0$ & 1.09E-07 & 4.33E-08 & 2.72E-07 & $1.36 \mathrm{E}-10$ & 2.70E-07 & $3.46 \mathrm{E}-08$ \\
\hline 2007 & 2 & $10,695,960.0$ & 1.09E-07 & 5.02E-08 & 2.36E-07 & 3.98E-08 & 4.88E-07 & $1.74 \mathrm{E}-07$ \\
\hline 2008 & 2 & $10,704,720.0$ & 1.09E-07 & 5.65E-08 & 2.10E-07 & 3.98E-08 & 4.88E-07 & $1.74 \mathrm{E}-07$ \\
\hline 2009 & 1 & $10,687,200.0$ & 1.09E-07 & $6.05 \mathrm{E}-08$ & 1.97E-07 & $1.22 \mathrm{E}-08$ & 3.85E-07 & $1.04 \mathrm{E}-07$ \\
\hline 2010 & 1 & $10,687,200.0$ & $1.10 \mathrm{E}-07$ & 6.07E-08 & $1.98 \mathrm{E}-07$ & $1.22 \mathrm{E}-08$ & 3.85E-07 & $1.04 \mathrm{E}-07$ \\
\hline 2011 & 3 & $10,844,880.0$ & 1.10E-07 & 5.70E-08 & 2.12E-07 & 7.45E-08 & 5.82E-07 & $2.41 \mathrm{E}-07$ \\
\hline 2012 & 3 & $10,748,520.0$ & $1.10 \mathrm{E}-07$ & $5.10 \mathrm{E}-08$ & 2.38E-07 & 7.50E-08 & 5.85E-07 & $2.42 \mathrm{E}-07$ \\
\hline 2013 & 1 & $10,766,040.0$ & 1.10E-07 & 4.42E-08 & 2.76E-07 & $1.22 \mathrm{E}-08$ & 3.83E-07 & $1.04 \mathrm{E}-07$ \\
\hline 2014 & 0 & $10,757,280.0$ & $1.11 \mathrm{E}-07$ & $3.76 \mathrm{E}-08$ & $3.25 \mathrm{E}-07$ & $1.36 \mathrm{E}-10$ & 2.70E-07 & $3.46 \mathrm{E}-08$ \\
\hline Total & 33 & $181,980,240.0$ & & & & & & \\
\hline
\end{tabular}


Table 15. Plot data for Figure 6, failure rate estimate trend for AOV SO, all systems, industry-wide trend of high-demand AOVs.

\begin{tabular}{|c|c|c|c|c|c|c|c|c|}
\hline \multirow[b]{2}{*}{$\begin{array}{c}\text { FYI } \\
\text { Source }\end{array}$} & \multirow[b]{2}{*}{ Failures } & \multirow[b]{2}{*}{ Hours } & \multicolumn{3}{|c|}{ Regression Curve Data Points } & \multicolumn{3}{|c|}{ Yearly Estimate Data Points } \\
\hline & & & Mean & $\begin{array}{l}\text { Lower } \\
(5 \%)\end{array}$ & $\begin{array}{l}\text { Upper } \\
(95 \%)\end{array}$ & $\begin{array}{c}\text { Lower } \\
(5 \%)\end{array}$ & $\begin{array}{l}\text { Upper } \\
(95 \%)\end{array}$ & Mean \\
\hline \multicolumn{2}{|c|}{2010 Update } & & & & & 2.04E-09 & 4.49E-07 & 1.31E-07 \\
\hline 1998 & 3 & $7,568,640.0$ & & & & $9.44 \mathrm{E}-08$ & 7.37E-07 & 3.05E-07 \\
\hline 1999 & 3 & $7,594,920.0$ & & & & $9.42 \mathrm{E}-08$ & 7.35E-07 & 3.04E-07 \\
\hline 2000 & 0 & $7,612,440.0$ & & & & $1.71 \mathrm{E}-10$ & 3.39E-07 & 4.34E-08 \\
\hline 2001 & 3 & $7,516,080.0$ & & & & $9.48 \mathrm{E}-08$ & $7.40 \mathrm{E}-07$ & 3.06E-07 \\
\hline 2002 & 1 & $7,568,640.0$ & & & & $1.53 \mathrm{E}-08$ & $4.82 \mathrm{E}-07$ & $1.31 \mathrm{E}-07$ \\
\hline 2003 & 0 & $7,533,600.0$ & & & & $1.72 \mathrm{E}-10$ & $3.41 \mathrm{E}-07$ & 4.37E-08 \\
\hline 2004 & 0 & $7,533,600.0$ & & & & $1.72 \mathrm{E}-10$ & $3.41 \mathrm{E}-07$ & 4.37E-08 \\
\hline 2005 & 1 & $7,542,360.0$ & $1.45 \mathrm{E}-07$ & $5.22 \mathrm{E}-08$ & $4.02 \mathrm{E}-07$ & $1.54 \mathrm{E}-08$ & $4.83 \mathrm{E}-07$ & $1.31 \mathrm{E}-07$ \\
\hline 2006 & 1 & $7,507,320.0$ & 1.33E-07 & 5.61E-08 & 3.16E-07 & $1.54 \mathrm{E}-08$ & 4.85E-07 & $1.31 \mathrm{E}-07$ \\
\hline 2007 & 0 & $7,507,320.0$ & $1.22 \mathrm{E}-07$ & 5.91E-08 & $2.53 \mathrm{E}-07$ & $1.72 \mathrm{E}-10$ & $3.42 \mathrm{E}-07$ & 4.38E-08 \\
\hline 2008 & 2 & $7,524,840.0$ & $1.12 \mathrm{E}-07$ & $6.03 E-08$ & 2.09E-07 & 5.01E-08 & $6.15 \mathrm{E}-07$ & 2.19E-07 \\
\hline 2009 & 2 & $7,507,320.0$ & $1.03 \mathrm{E}-07$ & $5.86 \mathrm{E}-08$ & $1.82 \mathrm{E}-07$ & 5.02E-08 & $6.16 \mathrm{E}-07$ & 2.19E-07 \\
\hline 2010 & 1 & $7,410,960.0$ & $9.50 \mathrm{E}-08$ & 5.34E-08 & 1.69E-07 & $1.55 \mathrm{E}-08$ & 4.89E-07 & $1.32 \mathrm{E}-07$ \\
\hline 2011 & 0 & $7,428,480.0$ & 8.73E-08 & 4.57E-08 & 1.67E-07 & $1.73 \mathrm{E}-10$ & $3.45 \mathrm{E}-07$ & 4.41E-08 \\
\hline 2012 & 2 & $7,314,600.0$ & 8.02E-08 & 3.74E-08 & $1.72 \mathrm{E}-07$ & 5.10E-08 & $6.27 \mathrm{E}-07$ & 2.23E-07 \\
\hline 2013 & 0 & $7,297,080.0$ & 7.37E-08 & 2.98E-08 & $1.82 \mathrm{E}-07$ & $1.75 \mathrm{E}-10$ & 3.49E-07 & 4.46E-08 \\
\hline 2014 & 0 & $7,279,560.0$ & $6.77 \mathrm{E}-08$ & 2.33E-08 & 1.97E-07 & $1.76 \mathrm{E}-10$ & $3.49 \mathrm{E}-07$ & 4.47E-08 \\
\hline Total & 19 & $127,247,760.0$ & & & & & & \\
\hline
\end{tabular}


Table 16. Plot data for Figure 7, frequency (demands per reactor year) of low-demand AOV FTOC demands

\begin{tabular}{ccccccccc}
\hline & & & \multicolumn{2}{c}{ Regression Curve Data Points } & \multicolumn{2}{c}{ Yearly Estimate Data Points } \\
\cline { 6 - 9 } FY & Demands & $\begin{array}{c}\text { Reactor } \\
\text { Years }\end{array}$ & Mean & $\begin{array}{c}\text { Lower } \\
\mathbf{( 5 \% )}\end{array}$ & $\begin{array}{c}\text { Upper } \\
\mathbf{( 9 5 \% )}\end{array}$ & $\begin{array}{c}\text { Lower } \\
\mathbf{( 5 \% )}\end{array}$ & $\begin{array}{c}\text { Upper } \\
\mathbf{( 9 5 \% )}\end{array}$ & Mean \\
\hline 1998 & 8,445 & 87.0 & & & & $9.53 \mathrm{E}+01$ & $9.88 \mathrm{E}+01$ & $9.71 \mathrm{E}+01$ \\
\hline 1999 & 8,800 & 87.0 & & & & $9.94 \mathrm{E}+01$ & $1.03 \mathrm{E}+02$ & $1.01 \mathrm{E}+02$ \\
\hline 2000 & 8,454 & 87.2 & & & & $9.52 \mathrm{E}+01$ & $9.87 \mathrm{E}+01$ & $9.69 \mathrm{E}+01$ \\
\hline 2001 & 8,638 & 87.0 & & & & $9.75 \mathrm{E}+01$ & $1.01 \mathrm{E}+02$ & $9.93 \mathrm{E}+01$ \\
\hline 2002 & 8,854 & 87.0 & & & & $1.00 \mathrm{E}+02$ & $1.04 \mathrm{E}+02$ & $1.02 \mathrm{E}+02$ \\
\hline 2003 & 8,689 & 87.0 & & & & $9.81 \mathrm{E}+01$ & $1.02 \mathrm{E}+02$ & $9.99 \mathrm{E}+01$ \\
\hline 2004 & 8,806 & 87.2 & & & & $9.92 \mathrm{E}+01$ & $1.03 \mathrm{E}+02$ & $1.01 \mathrm{E}+02$ \\
\hline 2005 & 8,807 & 87.0 & $9.51 \mathrm{E}+01$ & $9.10 \mathrm{E}+01$ & $9.93 \mathrm{E}+01$ & $9.95 \mathrm{E}+01$ & $1.03 \mathrm{E}+02$ & $1.01 \mathrm{E}+02$ \\
\hline 2006 & 8,101 & 87.0 & $9.50 \mathrm{E}+01$ & $9.15 \mathrm{E}+01$ & $9.86 \mathrm{E}+01$ & $9.14 \mathrm{E}+01$ & $9.48 \mathrm{E}+01$ & $9.31 \mathrm{E}+01$ \\
\hline 2007 & 8,158 & 87.0 & $9.49 \mathrm{E}+01$ & $9.20 \mathrm{E}+01$ & $9.79 \mathrm{E}+01$ & $9.21 \mathrm{E}+01$ & $9.55 \mathrm{E}+01$ & $9.38 \mathrm{E}+01$ \\
\hline 2008 & 8,098 & 87.2 & $9.48 \mathrm{E}+01$ & $9.23 \mathrm{E}+01$ & $9.74 \mathrm{E}+01$ & $9.11 \mathrm{E}+01$ & $9.45 \mathrm{E}+01$ & $9.28 \mathrm{E}+01$ \\
\hline 2009 & 8,033 & 87.0 & $9.47 \mathrm{E}+01$ & $9.25 \mathrm{E}+01$ & $9.70 \mathrm{E}+01$ & $9.06 \mathrm{E}+01$ & $9.40 \mathrm{E}+01$ & $9.23 \mathrm{E}+01$ \\
\hline 2010 & 8,187 & 87.0 & $9.46 \mathrm{E}+01$ & $9.24 \mathrm{E}+01$ & $9.69 \mathrm{E}+01$ & $9.24 \mathrm{E}+01$ & $9.58 \mathrm{E}+01$ & $9.41 \mathrm{E}+01$ \\
\hline 2011 & 8,082 & 87.0 & $9.45 \mathrm{E}+01$ & $9.20 \mathrm{E}+01$ & $9.71 \mathrm{E}+01$ & $9.12 \mathrm{E}+01$ & $9.46 \mathrm{E}+01$ & $9.29 \mathrm{E}+01$ \\
\hline 2012 & 8,170 & 87.2 & $9.45 \mathrm{E}+01$ & $9.15 \mathrm{E}+01$ & $9.75 \mathrm{E}+01$ & $9.20 \mathrm{E}+01$ & $9.54 \mathrm{E}+01$ & $9.37 \mathrm{E}+01$ \\
\hline 2013 & 8,237 & 85.6 & $9.44 \mathrm{E}+01$ & $9.09 \mathrm{E}+01$ & $9.80 \mathrm{E}+01$ & $9.45 \mathrm{E}+01$ & $9.80 \mathrm{E}+01$ & $9.63 \mathrm{E}+01$ \\
\hline 2014 & 8,056 & 83.0 & $9.43 \mathrm{E}+01$ & $9.02 \mathrm{E}+01$ & $9.86 \mathrm{E}+01$ & $9.53 \mathrm{E}+01$ & $9.89 \mathrm{E}+01$ & $9.71 \mathrm{E}+01$ \\
\hline Total & 142,617 & $1,474.5$ & & & & & & \\
\hline
\end{tabular}


Table 17. Plot data for Figure 8, frequency (demands per reactor year) of high-demand AOV FTOC demands.

\begin{tabular}{ccccccccc}
\hline & & & \multicolumn{2}{c}{ Regression Curve Data Points } & \multicolumn{2}{c}{ Yearly Estimate Data Points } \\
\cline { 6 - 9 } FY & Demands & $\begin{array}{c}\text { Reactor } \\
\text { Years }\end{array}$ & Mean & $\begin{array}{c}\text { Lower } \\
\mathbf{( 5 \% )}\end{array}$ & $\begin{array}{c}\text { Upper } \\
\mathbf{( 9 5 \% )}\end{array}$ & $\begin{array}{c}\text { Lower } \\
\mathbf{( 5 \% )}\end{array}$ & $\begin{array}{c}\text { Upper } \\
\mathbf{( 9 5 \% )}\end{array}$ & Mean \\
\hline 1998 & 26,741 & 90.0 & & & & $2.94 \mathrm{E}+02$ & $3.00 \mathrm{E}+02$ & $2.97 \mathrm{E}+02$ \\
\hline 1999 & 28,609 & 90.0 & & & & $3.15 \mathrm{E}+02$ & $3.21 \mathrm{E}+02$ & $3.18 \mathrm{E}+02$ \\
\hline 2000 & 28,062 & 90.2 & & & & $3.08 \mathrm{E}+02$ & $3.14 \mathrm{E}+02$ & $3.11 \mathrm{E}+02$ \\
\hline 2001 & 27,408 & 90.0 & & & & $3.02 \mathrm{E}+02$ & $3.08 \mathrm{E}+02$ & $3.05 \mathrm{E}+02$ \\
\hline 2002 & 27,548 & 90.0 & & & & $3.03 \mathrm{E}+02$ & $3.09 \mathrm{E}+02$ & $3.06 \mathrm{E}+02$ \\
\hline 2003 & 28,042 & 90.0 & & & & $3.09 \mathrm{E}+02$ & $3.15 \mathrm{E}+02$ & $3.12 \mathrm{E}+02$ \\
\hline 2004 & 27,443 & 90.2 & & & & $3.01 \mathrm{E}+02$ & $3.07 \mathrm{E}+02$ & $3.04 \mathrm{E}+02$ \\
\hline 2005 & 27,541 & 90.0 & $3.07 \mathrm{E}+02$ & $3.03 \mathrm{E}+02$ & $3.12 \mathrm{E}+02$ & $3.03 \mathrm{E}+02$ & $3.09 \mathrm{E}+02$ & $3.06 \mathrm{E}+02$ \\
\hline 2006 & 27,408 & 90.0 & $3.06 \mathrm{E}+02$ & $3.03 \mathrm{E}+02$ & $3.10 \mathrm{E}+02$ & $3.02 \mathrm{E}+02$ & $3.08 \mathrm{E}+02$ & $3.05 \mathrm{E}+02$ \\
\hline 2007 & 27,871 & 90.0 & $3.05 \mathrm{E}+02$ & $3.02 \mathrm{E}+02$ & $3.08 \mathrm{E}+02$ & $3.07 \mathrm{E}+02$ & $3.13 \mathrm{E}+02$ & $3.10 \mathrm{E}+02$ \\
\hline 2008 & 27,770 & 90.2 & $3.04 \mathrm{E}+02$ & $3.02 \mathrm{E}+02$ & $3.07 \mathrm{E}+02$ & $3.05 \mathrm{E}+02$ & $3.11 \mathrm{E}+02$ & $3.08 \mathrm{E}+02$ \\
\hline 2009 & 27,127 & 90.0 & $3.03 \mathrm{E}+02$ & $3.01 \mathrm{E}+02$ & $3.06 \mathrm{E}+02$ & $2.98 \mathrm{E}+02$ & $3.04 \mathrm{E}+02$ & $3.01 \mathrm{E}+02$ \\
\hline 2010 & 27,075 & 90.0 & $3.02 \mathrm{E}+02$ & $3.00 \mathrm{E}+02$ & $3.05 \mathrm{E}+02$ & $2.98 \mathrm{E}+02$ & $3.04 \mathrm{E}+02$ & $3.01 \mathrm{E}+02$ \\
\hline 2011 & 27,056 & 90.0 & $3.01 \mathrm{E}+02$ & $2.99 \mathrm{E}+02$ & $3.04 \mathrm{E}+02$ & $2.98 \mathrm{E}+02$ & $3.04 \mathrm{E}+02$ & $3.01 \mathrm{E}+02$ \\
\hline 2012 & 26,692 & 90.2 & $3.00 \mathrm{E}+02$ & $2.97 \mathrm{E}+02$ & $3.03 \mathrm{E}+02$ & $2.93 \mathrm{E}+02$ & $2.99 \mathrm{E}+02$ & $2.96 \mathrm{E}+02$ \\
\hline 2013 & 26,675 & 89.1 & $2.99 \mathrm{E}+02$ & $2.95 \mathrm{E}+02$ & $3.03 \mathrm{E}+02$ & $2.96 \mathrm{E}+02$ & $3.02 \mathrm{E}+02$ & $2.99 \mathrm{E}+02$ \\
\hline 2014 & 26,530 & 88.0 & $2.98 \mathrm{E}+02$ & $2.94 \mathrm{E}+02$ & $3.03 \mathrm{E}+02$ & $2.98 \mathrm{E}+02$ & $3.05 \mathrm{E}+02$ & $3.01 \mathrm{E}+02$ \\
\hline Total & 465,598 & $1,528.1$ & & & & & & \\
\hline
\end{tabular}


Table 18. Plot data for Figure 9, frequency (failures per reactor year) of low-demand AOV FTOC events.

\begin{tabular}{ccccccccc}
\hline & & & \multicolumn{2}{c}{ Regression Curve Data Points } & \multicolumn{2}{c}{ Yearly Estimate Data Points } \\
\cline { 6 - 9 } FY & Failures & $\begin{array}{c}\text { Reactor } \\
\text { Years }\end{array}$ & Mean & $\begin{array}{c}\text { Lower } \\
\mathbf{( 5 \% )}\end{array}$ & $\begin{array}{c}\text { Upper } \\
\mathbf{( 9 5 \% )}\end{array}$ & $\begin{array}{c}\text { Lower } \\
\mathbf{( 5 \% )}\end{array}$ & $\begin{array}{c}\text { Upper } \\
\mathbf{( 9 5 \% )}\end{array}$ & Mean \\
\hline 1998 & 10 & 87.0 & & & & $6.18 \mathrm{E}-02$ & $1.87 \mathrm{E}-01$ & $1.12 \mathrm{E}-01$ \\
\hline 1999 & 7 & 87.0 & & & & $3.87 \mathrm{E}-02$ & $1.47 \mathrm{E}-01$ & $7.99 \mathrm{E}-02$ \\
\hline 2000 & 4 & 87.2 & & & & $1.77 \mathrm{E}-02$ & $1.05 \mathrm{E}-01$ & $4.78 \mathrm{E}-02$ \\
\hline 2001 & 8 & 87.0 & & & & $4.62 \mathrm{E}-02$ & $1.61 \mathrm{E}-01$ & $9.06 \mathrm{E}-02$ \\
\hline 2002 & 7 & 87.0 & & & & $3.87 \mathrm{E}-02$ & $1.47 \mathrm{E}-01$ & $7.99 \mathrm{E}-02$ \\
\hline 2003 & 9 & 87.0 & & & & $5.39 \mathrm{E}-02$ & $1.74 \mathrm{E}-01$ & $1.01 \mathrm{E}-01$ \\
\hline 2004 & 6 & 87.2 & & & & $3.13 \mathrm{E}-02$ & $1.33 \mathrm{E}-01$ & $6.91 \mathrm{E}-02$ \\
\hline 2005 & 5 & 87.0 & $7.13 \mathrm{E}-02$ & $4.16 \mathrm{E}-02$ & $1.22 \mathrm{E}-01$ & $2.44 \mathrm{E}-02$ & $1.19 \mathrm{E}-01$ & $5.86 \mathrm{E}-02$ \\
\hline 2006 & 8 & 87.0 & $7.07 \mathrm{E}-02$ & $4.48 \mathrm{E}-02$ & $1.12 \mathrm{E}-01$ & $4.62 \mathrm{E}-02$ & $1.61 \mathrm{E}-01$ & $9.06 \mathrm{E}-02$ \\
\hline 2007 & 6 & 87.0 & $7.01 \mathrm{E}-02$ & $4.78 \mathrm{E}-02$ & $1.03 \mathrm{E}-01$ & $3.14 \mathrm{E}-02$ & $1.33 \mathrm{E}-01$ & $6.93 \mathrm{E}-02$ \\
\hline 2008 & 5 & 87.2 & $6.95 \mathrm{E}-02$ & $5.02 \mathrm{E}-02$ & $9.64 \mathrm{E}-02$ & $2.43 \mathrm{E}-02$ & $1.19 \mathrm{E}-01$ & $5.85 \mathrm{E}-02$ \\
\hline 2009 & 5 & 87.0 & $6.90 \mathrm{E}-02$ & $5.13 \mathrm{E}-02$ & $9.27 \mathrm{E}-02$ & $2.44 \mathrm{E}-02$ & $1.19 \mathrm{E}-01$ & $5.86 \mathrm{E}-02$ \\
\hline 2010 & 7 & 87.0 & $6.84 \mathrm{E}-02$ & $5.07 \mathrm{E}-02$ & $9.22 \mathrm{E}-02$ & $3.87 \mathrm{E}-02$ & $1.47 \mathrm{E}-01$ & $7.99 \mathrm{E}-02$ \\
\hline 2011 & 13 & 87.0 & $6.78 \mathrm{E}-02$ & $4.85 \mathrm{E}-02$ & $9.47 \mathrm{E}-02$ & $8.61 \mathrm{E}-02$ & $2.27 \mathrm{E}-01$ & $1.44 \mathrm{E}-01$ \\
\hline 2012 & 3 & 87.2 & $6.72 \mathrm{E}-02$ & $4.53 \mathrm{E}-02$ & $9.97 \mathrm{E}-02$ & $1.15 \mathrm{E}-02$ & $8.99 \mathrm{E}-02$ & $3.72 \mathrm{E}-02$ \\
\hline 2013 & 6 & 85.6 & $6.67 \mathrm{E}-02$ & $4.17 \mathrm{E}-02$ & $1.07 \mathrm{E}-01$ & $3.19 \mathrm{E}-02$ & $1.35 \mathrm{E}-01$ & $7.04 \mathrm{E}-02$ \\
\hline 2014 & 5 & 83.0 & $6.61 \mathrm{E}-02$ & $3.80 \mathrm{E}-02$ & $1.15 \mathrm{E}-01$ & $2.55 \mathrm{E}-02$ & $1.24 \mathrm{E}-01$ & $6.12 \mathrm{E}-02$ \\
\hline Total & 114 & $1,474.5$ & & & & & & \\
\hline
\end{tabular}


Table 19. Plot data for Figure 10, frequency (failures per reactor year) of high-demand AOV FTOC events.

\begin{tabular}{|c|c|c|c|c|c|c|c|c|}
\hline \multirow[b]{2}{*}{ FY } & \multirow[b]{2}{*}{ Failures } & \multirow[b]{2}{*}{$\begin{array}{c}\text { Reactor } \\
\text { Years }\end{array}$} & \multicolumn{3}{|c|}{ Regression Curve Data Points } & \multicolumn{3}{|c|}{ Yearly Estimate Data Points } \\
\hline & & & Mean & $\begin{array}{c}\text { Lower } \\
(5 \%)\end{array}$ & $\begin{array}{l}\text { Upper } \\
(95 \%)\end{array}$ & $\begin{array}{c}\text { Lower } \\
(5 \%)\end{array}$ & $\begin{array}{l}\text { Upper } \\
(95 \%)\end{array}$ & Mean \\
\hline 1998 & 12 & 90.0 & & & & 7.58E-02 & 2.08E-01 & $1.30 \mathrm{E}-01$ \\
\hline 1999 & 11 & 90.0 & & & & 6.79E-02 & $1.95 \mathrm{E}-01$ & 1.19E-01 \\
\hline 2000 & 8 & 90.2 & & & & 4.49E-02 & $1.56 \mathrm{E}-01$ & 8.80E-02 \\
\hline 2001 & 11 & 90.0 & & & & 6.79E-02 & $1.95 \mathrm{E}-01$ & 1.19E-01 \\
\hline 2002 & 5 & 90.0 & & & & 2.37E-02 & 1.16E-01 & $5.71 \mathrm{E}-02$ \\
\hline 2003 & 7 & 90.0 & & & & 3.77E-02 & $1.43 \mathrm{E}-01$ & 7.78E-02 \\
\hline 2004 & 8 & 90.2 & & & & 4.49E-02 & $1.56 \mathrm{E}-01$ & 8.80E-02 \\
\hline 2005 & 6 & 90.0 & 5.84E-02 & 2.68E-02 & 1.27E-01 & 3.06E-02 & $1.30 \mathrm{E}-01$ & $6.75 \mathrm{E}-02$ \\
\hline 2006 & 9 & 90.0 & 6.10E-02 & 3.14E-02 & 1.18E-01 & 5.25E-02 & 1.70E-01 & $9.86 \mathrm{E}-02$ \\
\hline 2007 & 2 & 90.0 & 6.37E-02 & 3.65E-02 & $1.11 \mathrm{E}-01$ & 5.94E-03 & 7.30E-02 & $2.59 \mathrm{E}-02$ \\
\hline 2008 & 8 & 90.2 & 6.65E-02 & 4.15E-02 & 1.07E-01 & 4.49E-02 & $1.56 \mathrm{E}-01$ & 8.80E-02 \\
\hline 2009 & 7 & 90.0 & 6.95E-02 & 4.59E-02 & $1.05 \mathrm{E}-01$ & 3.77E-02 & 1.43E-01 & 7.78E-02 \\
\hline 2010 & 8 & 90.0 & 7.25E-02 & 4.86E-02 & $1.08 \mathrm{E}-01$ & 4.50E-02 & 1.56E-01 & 8.82E-02 \\
\hline 2011 & 7 & 90.0 & 7.58E-02 & 4.91E-02 & 1.17E-01 & 3.77E-02 & $1.43 \mathrm{E}-01$ & 7.78E-02 \\
\hline 2012 & 3 & 90.2 & 7.91E-02 & 4.78E-02 & $1.31 \mathrm{E}-01$ & 1.12E-02 & 8.76E-02 & 3.62E-02 \\
\hline 2013 & 7 & 89.1 & 8.26E-02 & 4.54E-02 & $1.51 \mathrm{E}-01$ & 3.80E-02 & $1.45 \mathrm{E}-01$ & 7.86E-02 \\
\hline 2014 & 13 & 88.0 & 8.63E-02 & 4.24E-02 & 1.76E-01 & 8.56E-02 & 2.25E-01 & 1.43E-01 \\
\hline Total & 132 & $1,528.1$ & & & & & & \\
\hline
\end{tabular}


Table 20. Plot data for Figure 11, frequency (failures per reactor year) of low-demand AOV FTOP events.

\begin{tabular}{|c|c|c|c|c|c|c|c|c|}
\hline \multirow[b]{2}{*}{ FY } & \multirow[b]{2}{*}{ Failures } & \multirow[b]{2}{*}{$\frac{\text { Reactor }}{\text { Years }}$} & \multicolumn{3}{|c|}{ Regression Curve Data Points } & \multicolumn{3}{|c|}{ Yearly Estimate Data Points } \\
\hline & & & Mean & $\frac{\text { Lower }}{(5 \%)}$ & $\frac{\text { Upper }}{(95 \%)}$ & $\frac{\text { Lower }}{(5 \%)}$ & $\frac{\text { Upper }}{(95 \%)}$ & Mean \\
\hline 1998 & $\underline{0}$ & $\underline{87.0}$ & & & & $1.71 \mathrm{E}-05$ & $3.40 \mathrm{E}-02$ & 4.35E-03 \\
\hline 1999 & $\underline{3}$ & $\underline{87.0}$ & & & & $9.43 \mathrm{E}-03$ & 7.36E-02 & $3.05 \mathrm{E}-02$ \\
\hline$\underline{2000}$ & 1 & $\underline{87.2}$ & & & & $1.53 \mathrm{E}-03$ & 4.81E-02 & $1.30 \mathrm{E}-02$ \\
\hline 2001 & $\underline{3}$ & 87.0 & & & & $9.43 \mathrm{E}-03$ & $7.36 \mathrm{E}-02$ & $3.05 \mathrm{E}-02$ \\
\hline 2002 & $\underline{2}$ & 87.0 & & & & $4.98 \mathrm{E}-03$ & $6.12 \mathrm{E}-02$ & $2.18 \mathrm{E}-02$ \\
\hline$\underline{2003}$ & 1 & 87.0 & & & & $1.53 \mathrm{E}-03$ & $4.82 \mathrm{E}-02$ & $1.31 \mathrm{E}-02$ \\
\hline 2004 & $\underline{0}$ & 87.2 & & & & $1.71 \mathrm{E}-05$ & $3.39 \mathrm{E}-02$ & $4.34 \mathrm{E}-03$ \\
\hline$\underline{2005}$ & $\underline{2}$ & $\underline{87.0}$ & $7.40 \mathrm{E}-03$ & $3.09 \mathrm{E}-03$ & $1.77 \mathrm{E}-02$ & $4.98 \mathrm{E}-03$ & 6.12E-02 & $2.18 \mathrm{E}-02$ \\
\hline 2006 & $\underline{0}$ & 87.0 & $\overline{8.60 \mathrm{E}-03}$ & $4.07 \mathrm{E}-03$ & $1.82 \mathrm{E}-02$ & $\overline{1.71 \mathrm{E}-05}$ & $3.40 \mathrm{E}-02$ & $4.35 \mathrm{E}-03$ \\
\hline 2007 & $\underline{0}$ & 87.0 & $1.00 \mathrm{E}-02$ & $5.33 \mathrm{E}-03$ & $1.88 \mathrm{E}-02$ & $1.71 \mathrm{E}-05$ & $3.40 \mathrm{E}-02$ & $4.35 \mathrm{E}-03$ \\
\hline 2008 & $\underline{2}$ & 87.2 & $1.16 \mathrm{E}-02$ & $6.84 \mathrm{E}-03$ & $1.98 \mathrm{E}-02$ & 4.97E-03 & $6.11 \mathrm{E}-02$ & $2.17 \mathrm{E}-02$ \\
\hline 2009 & 1 & $\underline{87.0}$ & $1.35 \mathrm{E}-02$ & 8.53E-03 & $2.15 \mathrm{E}-02$ & $1.53 \mathrm{E}-03$ & $4.82 \mathrm{E}-02$ & $1.31 \mathrm{E}-02$ \\
\hline 2010 & 1 & $\underline{87.0}$ & $1.57 \mathrm{E}-02$ & $1.02 \mathrm{E}-02$ & $2.43 \mathrm{E}-02$ & $1.53 \mathrm{E}-03$ & $4.82 \mathrm{E}-02$ & $1.31 \mathrm{E}-02$ \\
\hline$\underline{2011}$ & 1 & $\underline{87.0}$ & $1.83 \mathrm{E}-02$ & $1.16 \mathrm{E}-02$ & $2.90 \mathrm{E}-02$ & $1.53 \mathrm{E}-03$ & $4.82 \mathrm{E}-02$ & $1.31 \mathrm{E}-02$ \\
\hline$\underline{2012}$ & $\underline{2}$ & $\underline{87.2}$ & $2.13 \mathrm{E}-02$ & $1.25 \mathrm{E}-02$ & $3.61 \mathrm{E}-02$ & $4.97 \mathrm{E}-03$ & $\underline{6.11 \mathrm{E}-02}$ & $2.17 \mathrm{E}-02$ \\
\hline$\underline{2013}$ & $\underline{3}$ & $\underline{85.6}$ & $2.47 \mathrm{E}-02$ & $1.32 \mathrm{E}-02$ & $4.63 \mathrm{E}-02$ & $9.55 \mathrm{E}-03$ & 7.45E-02 & $3.08 \mathrm{E}-02$ \\
\hline 2014 & $\underline{3}$ & 83.0 & $2.88 \mathrm{E}-02$ & $1.37 \mathrm{E}-02$ & $\overline{6.04 \mathrm{E}-02}$ & $9.77 \mathrm{E}-03$ & 7.63E-02 & $3.16 \mathrm{E}-02$ \\
\hline Total & $\underline{25}$ & $1,474.5$ & & & & & & \\
\hline
\end{tabular}


Table 21. Plot data for Figure 12, frequency (failures per reactor year) of high-demand AOV FTOP events.

\begin{tabular}{ccccccccc}
\hline & & & \multicolumn{2}{c}{ Regression Curve Data Points } & \multicolumn{2}{c}{ Yearly Estimate Data Points } \\
\cline { 6 - 8 } FY & Failures & $\begin{array}{c}\text { Reactor } \\
\text { Years }\end{array}$ & Mean & $\begin{array}{c}\text { Lower } \\
\mathbf{( 5 \% )}\end{array}$ & $\begin{array}{c}\text { Upper } \\
\mathbf{( 9 5 \% )}\end{array}$ & $\begin{array}{c}\text { Lower } \\
\mathbf{( 5 \% )}\end{array}$ & $\begin{array}{c}\text { Upper } \\
\mathbf{( 9 5 \% )}\end{array}$ & Mean \\
\hline 1998 & 3 & 90.0 & & & & $1.02 \mathrm{E}-02$ & $8.00 \mathrm{E}-02$ & $3.31 \mathrm{E}-02$ \\
\hline 1999 & 3 & 90.0 & & & & $1.02 \mathrm{E}-02$ & $8.00 \mathrm{E}-02$ & $3.31 \mathrm{E}-02$ \\
\hline 2000 & 6 & 90.2 & & & & $2.78 \mathrm{E}-02$ & $1.18 \mathrm{E}-01$ & $6.13 \mathrm{E}-02$ \\
\hline 2001 & 2 & 90.0 & & & & $5.42 \mathrm{E}-03$ & $6.65 \mathrm{E}-02$ & $2.36 \mathrm{E}-02$ \\
\hline 2002 & 2 & 90.0 & & & & $5.42 \mathrm{E}-03$ & $6.65 \mathrm{E}-02$ & $2.36 \mathrm{E}-02$ \\
\hline 2003 & 3 & 90.0 & & & & $1.02 \mathrm{E}-02$ & $8.00 \mathrm{E}-02$ & $3.31 \mathrm{E}-02$ \\
\hline 2004 & 2 & 90.2 & & & & $5.40 \mathrm{E}-03$ & $6.64 \mathrm{E}-02$ & $2.36 \mathrm{E}-02$ \\
\hline 2005 & 4 & 90.0 & $1.63 \mathrm{E}-02$ & $6.70 \mathrm{E}-03$ & $3.97 \mathrm{E}-02$ & $1.57 \mathrm{E}-02$ & $9.30 \mathrm{E}-02$ & $4.26 \mathrm{E}-02$ \\
\hline 2006 & 0 & 90.0 & $1.83 \mathrm{E}-02$ & $8.54 \mathrm{E}-03$ & $3.91 \mathrm{E}-02$ & $1.86 \mathrm{E}-05$ & $3.69 \mathrm{E}-02$ & $4.73 \mathrm{E}-03$ \\
\hline 2007 & 2 & 90.0 & $2.05 \mathrm{E}-02$ & $1.08 \mathrm{E}-02$ & $3.88 \mathrm{E}-02$ & $5.42 \mathrm{E}-03$ & $6.65 \mathrm{E}-02$ & $2.36 \mathrm{E}-02$ \\
\hline 2008 & 3 & 90.2 & $2.29 \mathrm{E}-02$ & $1.34 \mathrm{E}-02$ & $3.93 \mathrm{E}-02$ & $1.02 \mathrm{E}-02$ & $7.98 \mathrm{E}-02$ & $3.30 \mathrm{E}-02$ \\
\hline 2009 & 2 & 90.0 & $2.57 \mathrm{E}-02$ & $1.61 \mathrm{E}-02$ & $4.08 \mathrm{E}-02$ & $5.42 \mathrm{E}-03$ & $6.65 \mathrm{E}-02$ & $2.36 \mathrm{E}-02$ \\
\hline 2010 & 3 & 90.0 & $2.87 \mathrm{E}-02$ & $1.86 \mathrm{E}-02$ & $4.43 \mathrm{E}-02$ & $1.02 \mathrm{E}-02$ & $8.00 \mathrm{E}-02$ & $3.31 \mathrm{E}-02$ \\
\hline 2011 & 2 & 90.0 & $3.22 \mathrm{E}-02$ & $2.04 \mathrm{E}-02$ & $5.07 \mathrm{E}-02$ & $5.42 \mathrm{E}-03$ & $6.65 \mathrm{E}-02$ & $2.36 \mathrm{E}-02$ \\
\hline 2012 & 3 & 90.2 & $3.60 \mathrm{E}-02$ & $2.14 \mathrm{E}-02$ & $6.07 \mathrm{E}-02$ & $1.02 \mathrm{E}-02$ & $7.98 \mathrm{E}-02$ & $3.30 \mathrm{E}-02$ \\
\hline 2013 & 5 & 89.1 & $4.03 \mathrm{E}-02$ & $2.17 \mathrm{E}-02$ & $7.49 \mathrm{E}-02$ & $2.18 \mathrm{E}-02$ & $1.07 \mathrm{E}-01$ & $5.25 \mathrm{E}-02$ \\
\hline 2014 & 4 & 88.0 & $4.52 \mathrm{E}-02$ & $2.17 \mathrm{E}-02$ & $9.43 \mathrm{E}-02$ & $1.60 \mathrm{E}-02$ & $9.48 \mathrm{E}-02$ & $4.34 \mathrm{E}-02$ \\
\hline Total & 49 & $1,528.1$ & & & & & & \\
\hline
\end{tabular}


Table 22. Plot data for Figure 13, frequency (failures per reactor year) of low-demand AOV SO events.

\begin{tabular}{ccccccccc}
\hline & & & \multicolumn{2}{c}{ Regression Curve Data Points } & \multicolumn{2}{c}{ Yearly Estimate Data Points } \\
\cline { 6 - 8 } FY & Failures & $\begin{array}{c}\text { Reactor } \\
\text { Years }\end{array}$ & Mean & $\begin{array}{c}\text { Lower } \\
\mathbf{( 5 \% )}\end{array}$ & $\begin{array}{c}\text { Upper } \\
\mathbf{( 9 5 \% )}\end{array}$ & $\begin{array}{c}\text { Lower } \\
\mathbf{( 5 \% )}\end{array}$ & $\begin{array}{c}\text { Upper } \\
\mathbf{( 9 5 \% )}\end{array}$ & Mean \\
\hline 1998 & 0 & 87.0 & & & & $1.68 \mathrm{E}-05$ & $3.34 \mathrm{E}-02$ & $4.28 \mathrm{E}-03$ \\
1999 & 6 & 87.0 & & & & $2.52 \mathrm{E}-02$ & $1.07 \mathrm{E}-01$ & $5.56 \mathrm{E}-02$ \\
\hline 2000 & 1 & 87.2 & & & & $1.50 \mathrm{E}-03$ & $4.73 \mathrm{E}-02$ & $1.28 \mathrm{E}-02$ \\
\hline 2001 & 1 & 87.0 & & & & $1.51 \mathrm{E}-03$ & $4.74 \mathrm{E}-02$ & $1.28 \mathrm{E}-02$ \\
\hline 2002 & 8 & 87.0 & & & & $3.71 \mathrm{E}-02$ & $1.29 \mathrm{E}-01$ & $7.28 \mathrm{E}-02$ \\
\hline 2003 & 2 & 87.0 & & & & $4.90 \mathrm{E}-03$ & $6.02 \mathrm{E}-02$ & $2.14 \mathrm{E}-02$ \\
\hline 2004 & 1 & 87.2 & & & & $1.50 \mathrm{E}-03$ & $4.73 \mathrm{E}-02$ & $1.28 \mathrm{E}-02$ \\
\hline 2005 & 1 & 87.0 & $1.33 \mathrm{E}-02$ & $4.54 \mathrm{E}-03$ & $3.87 \mathrm{E}-02$ & $1.51 \mathrm{E}-03$ & $4.74 \mathrm{E}-02$ & $1.28 \mathrm{E}-02$ \\
\hline 2006 & 0 & 87.0 & $1.33 \mathrm{E}-02$ & $5.38 \mathrm{E}-03$ & $3.31 \mathrm{E}-02$ & $1.68 \mathrm{E}-05$ & $3.34 \mathrm{E}-02$ & $4.28 \mathrm{E}-03$ \\
\hline 2007 & 2 & 87.0 & $1.34 \mathrm{E}-02$ & $6.25 \mathrm{E}-03$ & $2.88 \mathrm{E}-02$ & $4.90 \mathrm{E}-03$ & $6.02 \mathrm{E}-02$ & $2.14 \mathrm{E}-02$ \\
\hline 2008 & 2 & 87.2 & $1.35 \mathrm{E}-02$ & $7.05 \mathrm{E}-03$ & $2.58 \mathrm{E}-02$ & $4.89 \mathrm{E}-03$ & $6.01 \mathrm{E}-02$ & $2.14 \mathrm{E}-02$ \\
\hline 2009 & 1 & 87.0 & $1.36 \mathrm{E}-02$ & $7.57 \mathrm{E}-03$ & $2.43 \mathrm{E}-02$ & $1.51 \mathrm{E}-03$ & $4.74 \mathrm{E}-02$ & $1.28 \mathrm{E}-02$ \\
\hline 2010 & 1 & 87.0 & $1.37 \mathrm{E}-02$ & $7.62 \mathrm{E}-03$ & $2.45 \mathrm{E}-02$ & $1.51 \mathrm{E}-03$ & $4.74 \mathrm{E}-02$ & $1.28 \mathrm{E}-02$ \\
\hline 2011 & 3 & 87.0 & $1.37 \mathrm{E}-02$ & $7.18 \mathrm{E}-03$ & $2.63 \mathrm{E}-02$ & $9.28 \mathrm{E}-03$ & $7.24 \mathrm{E}-02$ & $3.00 \mathrm{E}-02$ \\
\hline 2012 & 3 & 87.2 & $1.38 \mathrm{E}-02$ & $6.45 \mathrm{E}-03$ & $2.96 \mathrm{E}-02$ & $9.26 \mathrm{E}-03$ & $7.23 \mathrm{E}-02$ & $2.99 \mathrm{E}-02$ \\
\hline 2013 & 1 & 85.6 & $1.39 \mathrm{E}-02$ & $5.61 \mathrm{E}-03$ & $3.44 \mathrm{E}-02$ & $1.52 \mathrm{E}-03$ & $4.80 \mathrm{E}-02$ & $1.30 \mathrm{E}-02$ \\
\hline 2014 & 0 & 83.0 & $1.40 \mathrm{E}-02$ & $4.80 \mathrm{E}-03$ & $4.07 \mathrm{E}-02$ & $1.74 \mathrm{E}-05$ & $3.46 \mathrm{E}-02$ & $4.43 \mathrm{E}-03$ \\
\hline Total & 33 & $1,474.5$ & & & & & & \\
\hline
\end{tabular}


Table 23. Plot data for Figure 14, frequency (failures per reactor year) of high-demand AOV SO events.

\begin{tabular}{ccccccccc}
\hline & & & \multicolumn{2}{c}{ Regression Curve Data Points } & \multicolumn{2}{c}{ Yearly Estimate Data Points } \\
\cline { 6 - 8 } FY & Failures & $\begin{array}{c}\text { Reactor } \\
\text { Years }\end{array}$ & Mean & $\begin{array}{c}\text { Lower } \\
\mathbf{( 5 \% )}\end{array}$ & $\begin{array}{c}\text { Upper } \\
\mathbf{( 9 5 \% )}\end{array}$ & $\begin{array}{c}\text { Lower } \\
\mathbf{( 5 \% )}\end{array}$ & $\begin{array}{c}\text { Upper } \\
\mathbf{( 9 5 \% )}\end{array}$ & Mean \\
\hline 1998 & 3 & 90.0 & & & & $7.90 \mathrm{E}-03$ & $6.16 \mathrm{E}-02$ & $2.55 \mathrm{E}-02$ \\
1999 & 3 & 90.0 & & & & $7.90 \mathrm{E}-03$ & $6.16 \mathrm{E}-02$ & $2.55 \mathrm{E}-02$ \\
\hline 2000 & 0 & 90.2 & & & & $1.43 \mathrm{E}-05$ & $2.84 \mathrm{E}-02$ & $3.64 \mathrm{E}-03$ \\
\hline 2001 & 3 & 90.0 & & & & $7.90 \mathrm{E}-03$ & $6.16 \mathrm{E}-02$ & $2.55 \mathrm{E}-02$ \\
\hline 2002 & 1 & 90.0 & & & & $1.28 \mathrm{E}-03$ & $4.03 \mathrm{E}-02$ & $1.09 \mathrm{E}-02$ \\
\hline 2003 & 0 & 90.0 & & & & $1.43 \mathrm{E}-05$ & $2.85 \mathrm{E}-02$ & $3.64 \mathrm{E}-03$ \\
\hline 2004 & 0 & 90.2 & & & & $1.43 \mathrm{E}-05$ & $2.84 \mathrm{E}-02$ & $3.64 \mathrm{E}-03$ \\
\hline 2005 & 1 & 90.0 & $1.21 \mathrm{E}-02$ & $4.37 \mathrm{E}-03$ & $3.34 \mathrm{E}-02$ & $1.28 \mathrm{E}-03$ & $4.03 \mathrm{E}-02$ & $1.09 \mathrm{E}-02$ \\
\hline 2006 & 1 & 90.0 & $1.11 \mathrm{E}-02$ & $4.68 \mathrm{E}-03$ & $2.63 \mathrm{E}-02$ & $1.28 \mathrm{E}-03$ & $4.03 \mathrm{E}-02$ & $1.09 \mathrm{E}-02$ \\
\hline 2007 & 0 & 90.0 & $1.02 \mathrm{E}-02$ & $4.92 \mathrm{E}-03$ & $2.10 \mathrm{E}-02$ & $1.43 \mathrm{E}-05$ & $2.85 \mathrm{E}-02$ & $3.64 \mathrm{E}-03$ \\
\hline 2008 & 2 & 90.2 & $9.33 \mathrm{E}-03$ & $5.02 \mathrm{E}-03$ & $1.74 \mathrm{E}-02$ & $4.17 \mathrm{E}-03$ & $5.12 \mathrm{E}-02$ & $1.82 \mathrm{E}-02$ \\
\hline 2009 & 2 & 90.0 & $8.56 \mathrm{E}-03$ & $4.86 \mathrm{E}-03$ & $1.51 \mathrm{E}-02$ & $4.17 \mathrm{E}-03$ & $5.12 \mathrm{E}-02$ & $1.82 \mathrm{E}-02$ \\
\hline 2010 & 1 & 90.0 & $7.86 \mathrm{E}-03$ & $4.42 \mathrm{E}-03$ & $1.40 \mathrm{E}-02$ & $1.28 \mathrm{E}-03$ & $4.03 \mathrm{E}-02$ & $1.09 \mathrm{E}-02$ \\
\hline 2011 & 0 & 90.0 & $7.21 \mathrm{E}-03$ & $3.78 \mathrm{E}-03$ & $1.37 \mathrm{E}-02$ & $1.43 \mathrm{E}-05$ & $2.85 \mathrm{E}-02$ & $3.64 \mathrm{E}-03$ \\
\hline 2012 & 2 & 90.2 & $6.61 \mathrm{E}-03$ & $3.09 \mathrm{E}-03$ & $1.41 \mathrm{E}-02$ & $4.17 \mathrm{E}-03$ & $5.12 \mathrm{E}-02$ & $1.82 \mathrm{E}-02$ \\
\hline 2013 & 0 & 89.1 & $6.07 \mathrm{E}-03$ & $2.46 \mathrm{E}-03$ & $1.50 \mathrm{E}-02$ & $1.44 \mathrm{E}-05$ & $2.87 \mathrm{E}-02$ & $3.67 \mathrm{E}-03$ \\
\hline 2014 & 0 & 88.0 & $5.57 \mathrm{E}-03$ & $1.92 \mathrm{E}-03$ & $1.61 \mathrm{E}-02$ & $1.45 \mathrm{E}-05$ & $2.89 \mathrm{E}-02$ & $3.70 \mathrm{E}-03$ \\
\hline Total & 19 & $1,528.1$ & & & & & & \\
\hline
\end{tabular}




\section{REFERENCES}

[1] U.S. Nuclear Regulatory Commission, "Industry Trends," 2015. [Online]. Available: http://www.nrc.gov/reactors/operating/oversight/industry-trends.html. [Accessed 2015].

[2] J. R. Houghton, "NUREG/CR-1715, Vol. 3, Compononent Performance Study - Air-Operated Valves, 1987-1998," U.S. Nuclear Regulatory Commission, Washington, DC 20555-0001, 2001.

[3] U.S. Nuclear Regulatory Commission, "Reactor Operational Experience Results and Databases, Industry Average Parameter Estimates," 2015. [Online]. Available: http://nrcoe.inl.gov/resultsdb/. [Accessed 2015].

[4] S. A. Eide, "NUREG/CR-6928, Industy-Average Performance of Components and Initiating Events at U.S. Commercial Nuclear Power Plants," U.S. Nuclear Regulatory Commission, Washington, DC, 2007.

[5] U.S. Nuclear Regulatory Commission, "Reactor Operational Experience Results and Databases, Overview and Reference," 2015. [Online]. Available: http://nrcoe.inl.gov/resultsdb/. [Accessed 2015]. 